\section{(A) Check for updates}

Cite this: Dalton Trans., 2021, 50 , 17361

Received 29th September 2021 Accepted 27th October 2021

DOI: 10.1039/d1dt03311e

rsc.li/dalton

\title{
Coupling of $\mathrm{CO}_{2}$ and epoxides catalysed by novel $\mathrm{N}$-fused mesoionic carbene complexes of nickel (II) $\uparrow$
}

\author{
Fabian A. Watt, $\neq^{a}$ Benedikt Sieland, $t^{\mathrm{a}}$ Nicole Dickmann, $t^{\mathrm{a}}$ Roland Schoch, ${ }^{\mathrm{a}}$ \\ Regine Herbst-Irmer, (D ${ }^{b}$ Holger Ott, (D) ${ }^{c}$ Jan Paradies, (D) a Dirk Kuckling ${ }^{a}$ and \\ Stephan Hohloch (D) *d
}

\begin{abstract}
We report the syntheses of two rigid mesoionic carbene (MIC) ligands with a carbazole backbone via an intramolecular Finkelstein-cyclisation cascade and investigate their coordination behavior towards nickel(I) acetate. Despite the nickel(I) carbene complexes $\mathbf{4 a , b}$ showing only minor differences in their chemical composition, they display curious differences in their chemical properties, e.g. solubility. Furthermore, the potential of these novel MIC complexes in the coupling of carbon dioxide and epoxides as well as the differences in reactivity compared to classical NHC-derived complexes are evaluated.
\end{abstract}

\section{Introduction}

Pincer-type ligands have opened many new avenues in modern-day chemistry, giving rise to stable and robust catalysts as well as allowing for the isolation of highly reactive metal complexes. ${ }^{1,2}$ Therefore, a large variety of neutral and monoanionic pincer ligands have been synthesised in the past decades (Fig. 1). ${ }^{2,3}$ Due to their unique profiles and modular chemical designs, especially regarding the nature of the coordinating donor atoms (ranging from $\mathrm{PNP},{ }^{4} \mathrm{PCP},{ }^{5} \mathrm{POP},{ }^{6} \mathrm{OCO},{ }^{7}$ $\mathrm{SCS},{ }^{8} \mathrm{CNC},{ }^{9}$ or $\mathrm{CCC}^{10}$ just to mention a few), numerous breakthroughs have been achieved. One moiety of ever-increasing focus in this context is the monoanionic carbazole fragment. Its planar and rigid geometry in combination with its persistent fluorescence and its unique ability to partake in redox-reactions led to a plethora of applications in catalysis and small molecule activation. ${ }^{11}$ However, until now most of the carbazole systems have been derived from the classical PNP substitution pattern, while CNC coordination motifs, e.g. by using

\footnotetext{
${ }^{a}$ Paderborn University, Faculty of Science, Department of Chemistry, Warburger Straße 100, 33098 Paderborn, Germany

${ }^{b}$ University of Göttingen, Institute of Inorganic Chemistry, Tammannstraße 4, 37077 Göttingen, Germany

${ }^{c}$ Bruker AXS GmbH, Östliche Rheinbrückenstraße 49, 76187 Karlsruhe, Germany ${ }^{d}$ University of Innsbruck, Faculty of Chemistry and Pharmacy, Institute of General, Inorganic and Theoretical Chemistry, Innrain 80-82, 6020 Innsbruck, Austria. E-mail: Stephan.Hohloch@uibk.ac.at

$\dagger$ Electronic supplementary information (ESI) available. CCDC 1996487, 1996486 and 1996485. For ESI and crystallographic data in CIF or other electronic format see DOI: $10.1039 / \mathrm{d} 1 \mathrm{dt} 03311 \mathrm{e}$

\$These authors contributed equally.
}

N-heterocyclic carbenes (NHCs), have found less attention. Nevertheless, seminal work by Kunz and coworkers ${ }^{12}$ has shown that carbazole derived CNC coordinating ligands are valuable precursors for the design of effective catalysts $^{13}$ and can stabilize highly reactive group 10 metal complexes (Fig. 2, top left). ${ }^{14}$ This is supported by a recent report of Lee and co-workers who showed that nickel(II) complexes (Fig. 2, top right) are potent catalysts in the copolymerisation of $\mathrm{CO}_{2}$ and cyclohexene oxide. $^{15}$ However, given the relatively high temperatures required for catalysis, especially in comparison to systems with early transition metals, ${ }^{16}$ we felt that the improvement of these catalysts should be a valuable goal.

One strategy for the improvement of the catalytic potential of NHC-derived catalysts in recent years was the exchange of the

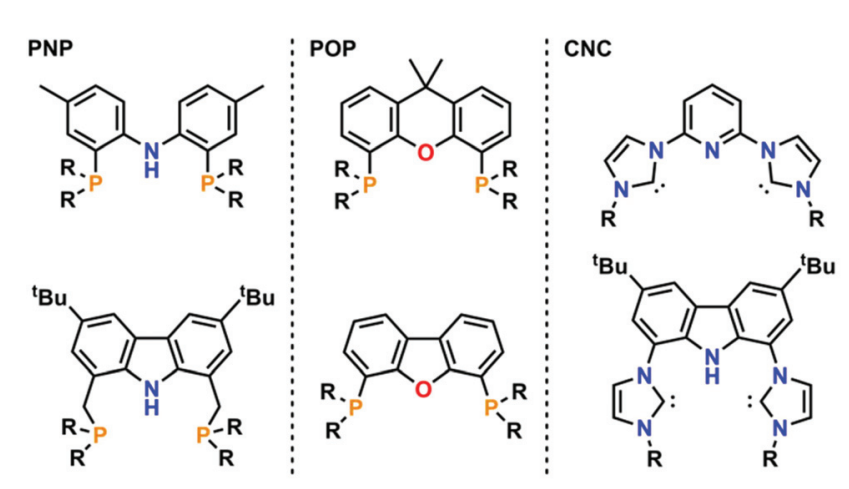

Fig. 1 Selected examples of the most commonly used pincer-type ligands scaffolds with PNP (left), POP (middle) and CNC (right) coordination modes. 

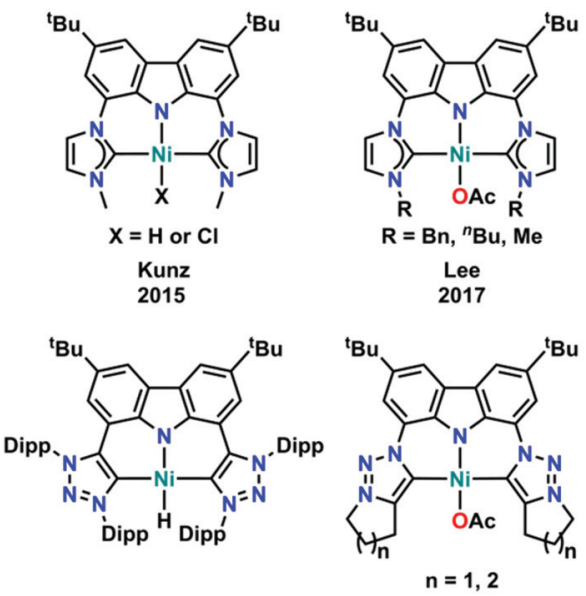

Bertrand \& Bezuidenhout 2014

This work

Fig. 2 Overview of all literature known carbene decorated nickel(II) carbazolide complexes, including the two new examples reported in this work.

NHC donors for mesoionic carbene (MIC) donors. ${ }^{17 \mathrm{j}, 18}$ Pioneering work by Sarkar and co-workers has shown that MICderived catalysts often exceed the catalytic potential of their NHC congeners. ${ }^{18,19,20-26}$ Transferring this concept to carbazolide-derived mesoionic carbenes, Bertrand and Bezuidenhout reported the first CNC pincer-type MIC ligands in 2014 (Fig. 2, bottom left). ${ }^{27}$ While this ligand was capable of stabilising a rare rhodium(I)-dioxygen adduct ${ }^{28}$ as well as a rare T-shaped gold(I) complex, ${ }^{29}$ its synthesis is tedious and requires the use of harmful and explosive reagents such as tert-butylhypochlorite and in situ generated 3-chlorotriazenes. Additionally, this synthetic route is limited by the availability of stable triazene derivatives, which means that it only serves to synthesise sterically demanding systems.

Aiming for a less hazardous synthetic protocol and reducing the steric bulk of carbazole-derived triazolium salts, we recently reported a tandem Finkelstein-cyclisation strategy which gave access to highly luminescent bis- $N$-fused triazolylidene carbazolide complexes of lithium and magnesium. ${ }^{30}$ In this contribution we investigate the coordination behaviour of these novel carbazole functionalized triazolylidene ligands towards nickel(II) and their application in the copolymerisation of $\mathrm{CO}_{2}$ with epoxides.

\section{Results and discussion}

To expand the versatility of our recently reported synthetic strategy to prepare bis(triazolylidene)-carbazolide ligands, ${ }^{30}$ in addition to the known compound $\mathbf{3 b}$ with a six-membered piperidine-based ring, we also synthesised ligand precursor $\mathbf{3 a}$ with a five-membered pyrrolidine-based annulated ring, which has a slightly lower steric bulk (Scheme 1). Compound 3a was synthesised using standard CuAAC (copper catalysed alkyne azide cycloaddition) conditions with 5-chloro-1-pentyne and 1,8-diazido-3,6-di-tert-butyl-carbazole, ${ }^{31}$ resulting in the clean formation of the desired chloro-propyl 1,2,3-triazole $2 \mathbf{a}$ in $70 \%$ yield (Scheme 1, middle). Indicative for the successful formation of the desired triazole is the disappearance of the characteristic azide stretching band in the IR spectrum at $2099 \mathrm{~cm}^{-1}$ (compare Fig. S53 and S54†). Additionally, successful formation of 2a was evidenced by ${ }^{1} \mathrm{H}$ NMR spectroscopy, showing a characteristic triazole- $5 \mathrm{H}$ low-field resonance at $\delta=8.02 \mathrm{ppm}$. Addition of an excess of potassium iodide (20 equiv.) and heating the mixture to $90{ }^{\circ} \mathrm{C}$ for $48 \mathrm{~h}$ led to the formation of the desired $N$-fused triazolium salt $\mathbf{3 a}$ in quantitative yields (Scheme 1, right). Successful cyclisation was evident by various features in the NMR spectra: (i) the typical low-field shift of the triazolium-5H resonance in the ${ }^{1} \mathrm{H}$ NMR spectrum from $\delta=8.02 \mathrm{ppm}$ for $2 \mathrm{a}$ to $\delta=8.67 \mathrm{ppm}$ for $\mathbf{3 a}$, (ii) the low-field shift of the resonance of the (former) $-\mathrm{CH}_{2} \mathrm{Cl}$ protons from $\delta=3.69 \mathrm{ppm}$ for $2 \mathrm{a}$ to $\delta=4.90 \mathrm{ppm}$ for $3 \mathrm{a}$, and (iii) the coupling of this methylene group to the triazole nitrogen atoms $\left(\delta\left({ }^{15} \mathrm{~N}\right)=266.6 \mathrm{ppm}\right)$ as seen in the ${ }^{1} \mathrm{H}^{-}{ }^{15} \mathrm{~N}$ HMBC NMR spectrum (compare Fig. S10 $\dagger$ ). Finally, X-ray quality crystals $^{32}$ of 3a were obtained by layering a concentrated dichloromethane solution with $n$-hexane in a NMR tube and storage at room temperature for several days. Compound 3a crystallises in the triclinic space group $P \overline{1}$ with five dichloromethane solvent molecules in the crystal lattice and two independent molecules in the asymmetric unit. Despite the relatively small change from an $N$-fused piperidine to a pyrrolidine ring, the structures of $\mathbf{3 a} \mathbf{a} \mathbf{b}$ reveal notable differences. While $\mathbf{3 a}$ shows hydrogen bonding of the carbazole-NH proton $\mathrm{H} 10$ to one of the iodide counterions (Fig. 3, left), in 3b such an interaction is absent. ${ }^{30}$ Apart from the hydrogen bonding, the structural parameters in $\mathbf{3 a}$ reflect the ones in $3 \mathbf{b}^{30}$ and previously reported 1,2,3-triazolium salts. ${ }^{20,22}$ A detailed discussion of

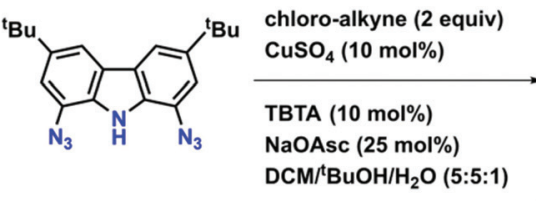

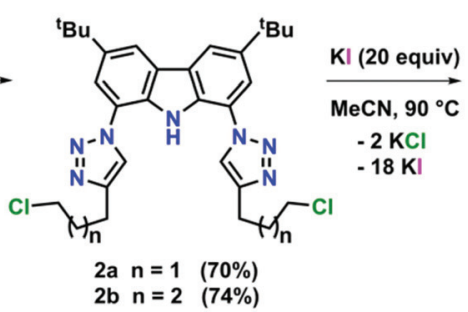

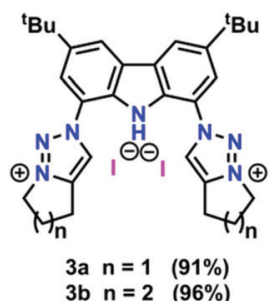

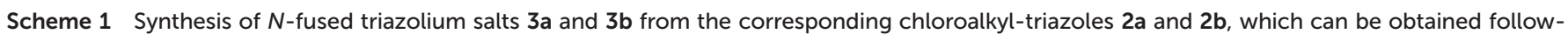

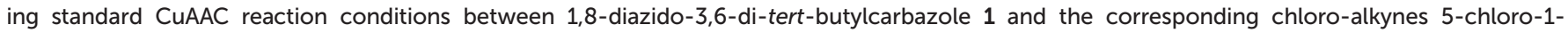
pentyne or 6-chloro-1-hexyne. 


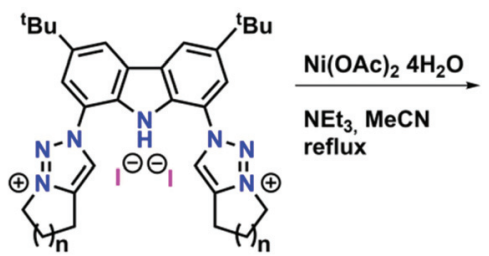

$3 a n=1$

$3 b \quad n=2$

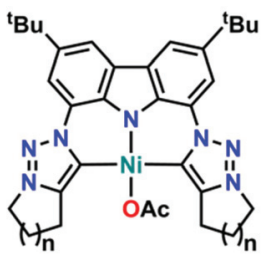

$4 a n=1 \quad(83 \%)$

$4 b \quad n=2 \quad(83 \%)$

Scheme 2 Synthesis of the nickel(II) triazolylidene complexes $4 a$ and 4b.

the structural parameters is therefore omitted. For more details on the structural metrics please see Tables S1 and S2 in the ESI $\dagger$ (Fig. 3).

Although mesoionic carbene complexes of nickel(II) are still scarce and often rely on the use of precursors which are unstable under ambient (air and moisture) conditions, such as nickelocene, ${ }^{33,34}$ we found that complexation could be achieved using $\mathrm{Ni}(\mathrm{OAc})_{2} \cdot 4 \mathrm{H}_{2} \mathrm{O}$ in the presence of excess triethylamine at $80{ }^{\circ} \mathrm{C}$ (see Scheme 2). Despite the fact that $4 a$ and $\mathbf{4 b}$ differ only by one methylene group, their solubility differs drastically. While complex $\mathbf{4 b}$ is soluble in a range of coordinating, aromatic and halogenated solvents, 4a does only dissolve to a minimal extent in halogenated or coordinating solvents, but is insoluble in aromatic solvents. Successful formation of the new triazolylidene nickel(II) complexes was supported by several features in the ${ }^{1} \mathrm{H}$ and ${ }^{13} \mathrm{C}\left\{{ }^{1} \mathrm{H}\right\}$ NMR spectra of the complexes: (i) the disappearance of the carbazole-NH and triazolium- $5 H$ resonances in the ${ }^{1} \mathrm{H}$ NMR spectra of the complexes (Fig. S11 and S16 ${ }^{\dagger}$ ) as well as the $\mathrm{NH}$ absorption band in the IR spectrum (Fig. S56 and S57†), (ii) a high-field shift of the resonance of the methylene protons adjacent to the triazole nitrogen atoms from $\delta=4.90 \mathrm{ppm}$ and $\delta=$ $4.79 \mathrm{ppm}$ for $3 \mathrm{a}$ and $3 \mathrm{~b}$ to $\delta=4.48 \mathrm{ppm}$ and $\delta=4.49 \mathrm{ppm}$ for 4a and $\mathbf{4 b}$ (compare Fig. S11 and S16 $\dagger$ ), and (iii) the presence of the characteristic triazolylidene-5C resonance at $\delta=$ $152.0 \mathrm{ppm}$ and $\delta=146.9 \mathrm{ppm}$ in the ${ }^{13} \mathrm{C}\left\{{ }^{1} \mathrm{H}\right\}$ NMR spectra of 4a and $\mathbf{4 b}$ (compare Fig. S12 and S17 $\dagger$ ), which are in a comparable range of previously reported nickel(II) triazolylidene

complexes. $^{33,34}$ Additionally, a signal at $\delta=177.7 \mathrm{ppm}$ and $\delta=$ $177.1 \mathrm{ppm}$ in the ${ }^{13} \mathrm{C}\left\{{ }^{1} \mathrm{H}\right\}$ NMR spectra of $\mathbf{4 a}$ and $\mathbf{4 b}$ was detected, corresponding to the carbonyl carbon atom of the acetate anion. Ultimate prove for the successful formation of the desired triazolylidene complexes $\mathbf{4 a}$ and $\mathbf{4 b}$ was given by X-ray diffraction analysis. Single crystals suitable for structure analysis were obtained by layering a concentrated dichloromethane solution of the respective complexes with $n$-hexane in an NMR tube at room temperature (Fig. 3, middle and right). Both compounds crystallise in the triclinic space group $P \overline{1}$ as either a water solvate (4a) or a dichloromethane solvate (4b). In both complexes the nickel(II) ion is in a slightly distorted square planar coordination environment, with N10-Ni1-O1 and C1-Ni1-C2 angles of 175.44(7) $\% / 176.30(9)^{\circ}(\mathbf{4 a})$ and 176.11 $(7)^{\circ} / 173.39(7)^{\circ}(\mathbf{4 b})$, as well as $\tau_{4}^{\prime}$ values of 0.06 and 0.07 in $4 \mathbf{a}$ and $\mathbf{4 b}$, respectively. The Ni1-N10 distances are 1.854(2) A (4a) and 1.861(2) $\AA$ (4b) and lie in the range of previously reported carbazolide and pyrrolide coordinated nickel(II) ions. ${ }^{14,27}$ The nickel-carbene carbon atom distances were found to be 1.945 (2) $\AA$ and 1.947(2) $\AA$ in 4a and 1.943(2) $\AA$ and 1.931(2) $\AA$ in $4 \mathbf{b}$ for Ni1-C1 and Ni1-C2, respectively. These distances also compare well to those of previously reported nickel(II) triazolylidene complexes. ${ }^{33,34}$ The intra ligand distances within the triazolylidene ring are in the expected region and comparable to previously reported triazolylidene complexes. ${ }^{21-26,33,34}$ Further information regarding the crystal structures and selected bond lengths and angles can be found in the ESI, Tables S1 and S2.†

Having the new complexes in hand, and given the fact, that MIC-derived complexes are known to often surpass their NHC congeners' activities in catalytic reactions, ${ }^{18}$ we next turned our focus towards their catalytic potential in the copolymerisation of carbon dioxide and cyclohexene oxide. Lee $e t$ al. ${ }^{15}$ have previously shown that corresponding NHC-derived catalysts (Fig. 1, top right) are moderately active catalysts for the polymerisations of carbon dioxide and cyclohexene oxide to give copolymers. Thus, we applied similar conditions to our catalysts and used cyclohexene oxide (CHO, Fig. 4) as monomer as well. The results for the catalysed coupling reactions of epoxide and carbon dioxide $\left(\mathrm{CO}_{2}\right)$ are shown in Table 1 . It is noteworthy that compared to the report by Lee and co-workers,
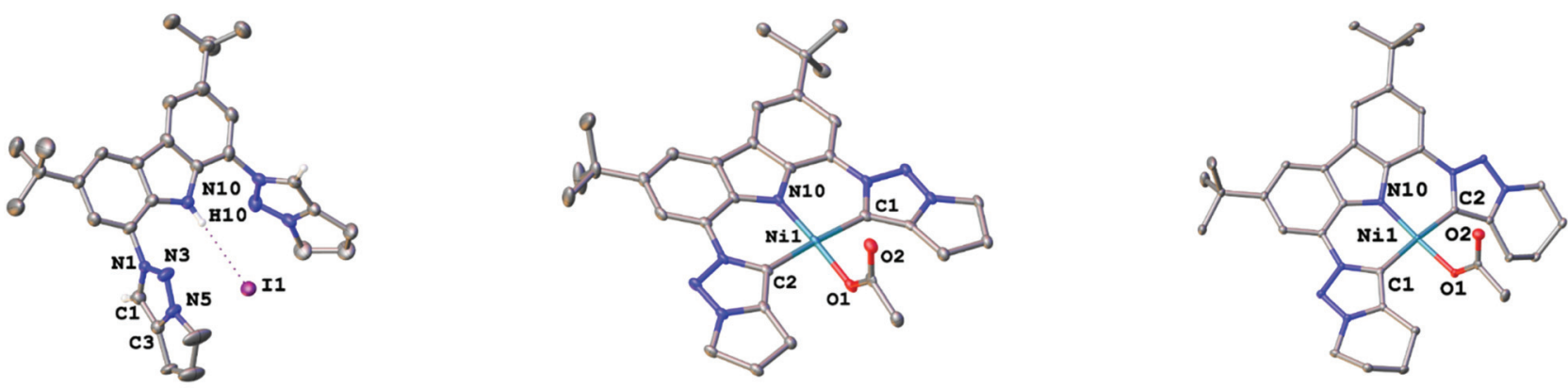

Fig. 3 Thermal ellipsoid plots of $3 a, 4 a$ and $4 b$ (left to right). Second iodide counteranion (3a), solvent atoms and hydrogen atoms have been omitted for clarity. Thermal ellipsoids are shown at a probability level of $50 \%$. 
Table 1 Overview of the performed catalytic reactions using pro-catalysts $4 a$ and $4 b$ as well as various epoxide monomers. All reactions were performed neat in a $2.77 \mathrm{mmol}$ scale with $0.1 \mathrm{~mol} \%$ catalyst and co-catalyst

\begin{tabular}{|c|c|c|c|c|c|c|c|c|c|c|}
\hline Entry & Epoxide & Cat. (mol\%) & Co-catalyst & Time $[\mathrm{h}]$ & $T\left[{ }^{\circ} \mathrm{C}\right]$ & $p \mathrm{CO}_{2}[\mathrm{bar}]$ & Epoxide conv. $^{a}[\%]$ & Ratio CC: $\mathrm{PE}^{a}$ & $\mathrm{TON}^{b, d}$ & $\mathrm{TOF}^{c, d}$ \\
\hline 1 & $\mathrm{CHO}$ & $\mathbf{4 a}(0.5)$ & - & 18 & 130 & 20 & 53 & $64: 36$ & 67 & 4 \\
\hline 2 & $\mathrm{CHO}$ & $\mathbf{4 b}(0.5)$ & - & 18 & 130 & 20 & 19 & $63: 37$ & 24 & 1 \\
\hline 3 & $\mathrm{CHO}$ & $4 a(0.25)$ & - & 18 & 130 & 20 & 50 & $33: 67$ & 67 & 4 \\
\hline 4 & $\mathrm{CHO}$ & $4 \mathbf{b}(0.25)$ & - & 18 & 130 & 20 & 55 & $24: 76$ & 53 & 3 \\
\hline $5^{e}$ & $\mathrm{CHO}$ & $4 \mathrm{a}(0.1)$ & - & 18 & 130 & 20 & 38 & $15: 85$ & 58 & 3 \\
\hline $6^{e}$ & $\mathrm{CHO}$ & $\mathbf{4 a}(0.1)$ & {$[\mathrm{PPN}] \mathrm{Cl}$} & 18 & 130 & 20 & 46 & $43: 57$ & 195 & 11 \\
\hline 7 & $\mathrm{CHO}$ & $\mathbf{4 b}(0.1)$ & - & 18 & 130 & 20 & 69 & $8: 92$ & 55 & 3 \\
\hline 8 & $\mathrm{CHO}$ & $\mathbf{4 b}(0.1)$ & [PPN]Cl & 18 & 130 & 20 & 70 & $32: 68$ & 220 & 12 \\
\hline 9 & $\mathrm{CHO}$ & $4 a(0.1)$ & - & 120 & 130 & 20 & 73 & $53: 47$ & 392 & 3 \\
\hline 10 & $\mathrm{CHO}$ & $4 \mathbf{a}(0.1)$ & {$[\mathrm{PPN}] \mathrm{Cl}$} & 120 & 130 & 20 & $>99$ & $100: 0$ & $>999$ & 8 \\
\hline 11 & $\mathrm{CHO}$ & $\mathbf{4 b}(0.1)$ & - & 120 & 130 & 20 & 95 & $78: 22$ & 739 & 6 \\
\hline 12 & $\mathrm{CHO}$ & $4 \mathbf{b}(0.1)$ & {$[\mathrm{PPN}] \mathrm{Cl}$} & 120 & 130 & 20 & $>99$ & $93: 7$ & 930 & 8 \\
\hline 13 & $\mathrm{CHO}$ & $4 \mathbf{a}(0.1)$ & {$[\mathrm{PPN}] \mathrm{Cl}$} & 18 & 130 & 2 & 4 & $37: 63$ & 16 & 1 \\
\hline 14 & $\mathrm{CHO}$ & $\mathbf{4 b}(0.1)$ & [PPN]Cl & 18 & 130 & 2 & 7 & $27: 73$ & 19 & 1 \\
\hline 15 & $\mathrm{CHO}$ & - & - & 18 & 130 & 20 & 85 & $0: 100$ & 0 & 0 \\
\hline 16 & $\mathrm{CHO}$ & - & {$[\mathrm{PPN}] \mathrm{Cl}$} & 18 & 130 & 20 & 56 & $53: 47$ & 301 & 17 \\
\hline 17 & CHO & - & - & 18 & 130 & - & 99 & $0: 100$ & 0 & 0 \\
\hline $18^{f}$ & GMPE & $4 a(0.1)$ & - & 18 & $\mathrm{RT}$ & 20 & 0 & - & 0 & 0 \\
\hline $19^{f}$ & GMPE & $4 a(0.1)$ & [PPN]Cl & 18 & $\mathrm{RT}$ & 20 & 0 & - & 0 & 0 \\
\hline $20^{f}$ & GMPE & $4 a(0.1)$ & - & 18 & 80 & 20 & 0 & - & 0 & 0 \\
\hline $21^{f}$ & GMPE & $\mathbf{4 a}(0.1)$ & {$[\mathrm{PPN}] \mathrm{Cl}$} & 18 & 80 & 20 & 15 & $100: 0$ & 153 & 8 \\
\hline 22 & GMPE & $4 a(0.1)$ & - & 18 & 130 & 20 & 41 & $100: 0$ & 411 & 23 \\
\hline 23 & GMPE & $4 \mathbf{a}(0.1)$ & {$[\mathrm{PPN}] \mathrm{Cl}$} & 18 & 130 & 20 & $>99$ & $100: 0$ & $>999$ & 55 \\
\hline 24 & GMPE & ab $(0.1)$ & - & 18 & 130 & 20 & $>99$ & $100: 0$ & $>999$ & 55 \\
\hline 25 & GMPE & $4 \mathbf{b}(0.1)$ & {$[\mathrm{PPN}] \mathrm{Cl}$} & 18 & 130 & 20 & $>99$ & $100: 0$ & $>999$ & 55 \\
\hline 26 & GMPE & - & - & 18 & 130 & 20 & 0 & - & 0 & 0 \\
\hline 27 & GMPE & - & {$[\mathrm{PPN}] \mathrm{Cl}$} & 18 & 130 & 20 & 11 & $100: 0$ & 110 & 6 \\
\hline 28 & AGE & $4 a(0.1)$ & - & 18 & 130 & 20 & 73 & $100: 0$ & 733 & 41 \\
\hline 29 & AGE & $4 \mathbf{a}(0.1)$ & {$[\mathrm{PPN}] \mathrm{Cl}$} & 18 & 130 & 20 & 98 & $100: 0$ & 981 & 54 \\
\hline 30 & AGE & $4 \mathbf{b}(0.1)$ & - & 18 & 130 & 20 & 96 & $100: 0$ & 962 & 53 \\
\hline 31 & AGE & $\mathbf{4 b}(0.1)$ & {$[\mathrm{PPN}] \mathrm{Cl}$} & 18 & 130 & 20 & 98 & $100: 0$ & 975 & 54 \\
\hline 32 & E5H & $\mathbf{4 a}(0.1)$ & - & 18 & 130 & 20 & 52 & $100: 0$ & 519 & 29 \\
\hline 33 & E5H & $\mathbf{4 a}(0.1)$ & {$[\mathrm{PPN}] \mathrm{Cl}$} & 18 & 130 & 20 & 77 & $100: 0$ & 770 & 43 \\
\hline 34 & E5H & $4 \mathbf{b}(0.1)$ & - & 18 & 130 & 20 & 33 & $100: 0$ & 331 & 18 \\
\hline 35 & E5H & $\mathbf{4 b}(0.1)$ & {$[\mathrm{PPN}] \mathrm{Cl}$} & 18 & 130 & 20 & 84 & $100: 0$ & 839 & 47 \\
\hline 36 & $t \mathrm{BOMC}$ & $4 a(0.1)$ & - & 18 & 130 & 20 & $>99$ & $48: 52$ & 482 & 27 \\
\hline 37 & $t \mathrm{BOMC}$ & $4 a(0.1)$ & {$[\mathrm{PPN}] \mathrm{Cl}$} & 18 & 130 & 20 & $>99$ & $82: 18$ & 820 & 46 \\
\hline 38 & $t$ BOMC & $\mathbf{4 b}(0.1)$ & - & 18 & 130 & 20 & $>99$ & $64: 36$ & 638 & 35 \\
\hline 39 & $t \mathrm{BOMC}$ & $4 \mathbf{b}(0.1)$ & {$[\mathrm{PPN}] \mathrm{Cl}$} & 18 & 130 & 20 & $>99$ & $81: 19$ & 808 & 45 \\
\hline
\end{tabular}

${ }^{a}$ Determined by ${ }^{1} \mathrm{H}$ NMR. ${ }^{b}$ TON $=$ moles of CC formed by mole of catalyst. ${ }^{c}$ TOF $=$ TON per hour. ${ }^{d}$ Both, TON and TOF were calculated on the basis of the epoxide conversion determined by ${ }^{1} \mathrm{H}$ NMR. ${ }^{e}$ Reaction performed in a 3.06 mmol scale. ${ }^{f}$ Performed in DCM.

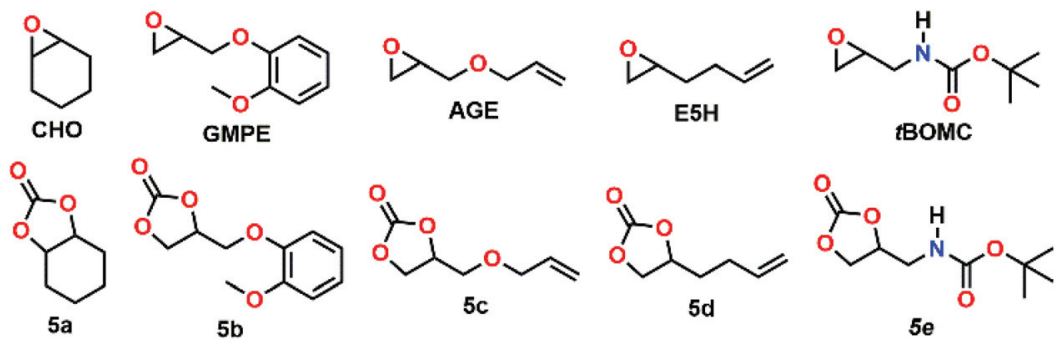

Fig. 4 Epoxides used for the coupling reaction with $\mathrm{CO}_{2}$. The corresponding cyclic carbonates $5 \mathrm{a}-5 \mathrm{e}$ are listed underneath.

who were able to apply a carbon dioxide pressure of 500 psi (34.5 bar), our synthetic setup was limited to a pressure of 290 psi (20 bar). Although it has been accepted as a common rule, that higher pressures favour the formation of polycarbonates, ${ }^{35,36}$ recent literature reports show that nickel (II)-based catalysts can efficiently couple carbon dioxide and 
epoxides to the desired polycarbonates even at 20 bar. $^{37}$ In an initial check, wether $\mathbf{4 a}$ and $\mathbf{4 b}$ could be active (pro)-catalysts in the copolymerisation of $\mathrm{CHO}$ and $\mathrm{CO}_{2}$, we applied different catalyst loadings $0.5,0.25$ and $0.1 \mathrm{~mol} \%$ of $\mathbf{4 a}$ or $\mathbf{4 b}$ (entries 1-5 and 7), similar to the experiments performed by Lee and co-workers. ${ }^{15}$ Crude ${ }^{1} \mathrm{H}$ NMR spectra of the reaction mixtures indicated the possible formation of polymers showing broad peaks (Fig. S21†). However, after work-up cyclic carbonate (CC) 5a was isolated as the sole product from these reactions. Notably, when the reaction was performed either without catalysts or without carbon dioxide, small amounts of polyether (PE) could be isolated (vide infra, entries 15-17).

While the TONs to CC seem to be barely affected by the catalyst loading for 4a (entries 1, 3 and 5), the formation of PE by-products increased with lower catalyst loadings. Contrary, for catalyst $\mathbf{4 b}$ (entries 2, 4 and 7), TONs as well as the formation of $\mathrm{PE}$ by-product increased concurrently with lower catalyst loadings. Applying the established cocatalyst bis(triphenyl-phosphine) iminium chloride ([PPN]Cl) (entries 6 and 8 ) resulted in higher conversion of the monomer and TONs/ TOFs up to $220 / 12 \mathrm{~h}^{-1}$. Since no significant polycarbonate formation could be detected for all of these conditions, we proceeded with the lowest catalyst loading $(0.1 \mathrm{~mol} \%)$ to improve the conditions leading to cyclic carbonates. Increasing the reaction time from $18 \mathrm{~h}$ to $120 \mathrm{~h}$ (entries 9-12) led to increasing amounts of cyclic carbonate $\mathbf{5 a}$, while polyether formation was suppressed. Similarly, the addition of [PPN]Cl shifted the selectivity of the reaction towards the formation of cyclic carbonates. Furthermore, complex 4a seems to have a lower activity at this catalyst loading compared to $\mathbf{4 b}$, which is most likely related to the lower solubility of $\mathbf{4 a}$. Reducing the carbon dioxide pressure to 2 bars (entries 13 and 14) resulted in a drastic drop of the conversions and a preferred formation of polyether. Notably, Mayilmurugan et al. have recently reported a nickel(II) complex, which is capable of performing efficient CC coupling at 1 bar and $100{ }^{\circ} \mathrm{C}^{38}$ No catalyst (entry 15) for CHO gave solely PE, only co-catalyst resulted in lower TOFs and $\mathrm{PE}$ by-product of $47 \%$ (entry 16). Heating of the monomer led to pure PE (entry 17).

Next we turned our interest towards the reactivity of other, functionalised epoxides, especially glycidyl ethers (see Fig. 4), ${ }^{39}$ in order to probe if the trends for cyclohexene oxide can be reproduced for other epoxides. Treating 3-(o-methoxyphenoxy)-1,2-epoxypropane (GMPE) (entries 18-27) under the same conditions as applied for our initial cyclohexene oxide studies $\left(130{ }^{\circ} \mathrm{C}, 20\right.$ bar of $\mathrm{CO}_{2}$ and $\left.18 \mathrm{~h}\right)$, the overall conversions for GMPE were found to be higher (entries 22-25). The TOF for complex $4 \mathbf{b}$ without co-catalyst was $>55 \mathrm{~h}^{-1}$ and the TOF for $4 \mathbf{a}$ only $23 \mathrm{~h}^{-1}$. Therefore, a higher reactivity of $\mathbf{4 b}$ for the reaction of GMPE to $\mathbf{5 b}$ can be assumed, which might as well be related to the higher solubility of $\mathbf{4} \mathbf{b}$. With increasing temperature, the formation of CC is entropically favoured over PC formation. Therefore, experiments with GMPE at RT (entries 18 and 19) and at $80{ }^{\circ} \mathrm{C}$ (entries 20 and 21) were performed. While at RT no reaction was observed, at $80{ }^{\circ} \mathrm{C}$ the use of complex $\mathbf{4 b}$ gave CC with a moderate TOF of $8 \mathrm{~h}^{-1}$. In all cases, the addition of [PPN]Cl resulted in a drastic enhancement of the catalytic activity of the systems. Using no catalyst and only co-catalyst for GMPE resulted in no conversion. Using no catalyst and only [PPN]Cl gave low TOFs of $6 \mathrm{~h}^{-1}$ (entries 26 and 27). The same trends were also observed for other glycidyl ethers such as allyl glycidyl ether (AGE, entries 28-31), and 1,2-epoxyhex-5-ene (E5H, entries 32-35).

Finally, we examined the influence of a protic substrate, for which purpose we synthesized tert-butyl(oxiran-2-ylmethyl)carbamate ( $t$ BOMC). Similar to the glycidyl ethers, full conversion of the starting material was achieved for both catalysts $\mathbf{4 a}$ and 4b. However, for $t$ BOMC the carbonate selectivity of the complexes dropped and the PE by-product was formed in significant amounts. Nevertheless, PE formation can be decreased by addition of [PPN]Cl as co-catalyst (entries 36-39).

\section{Conclusion}

We extended the route to 1,8-bis(1,2,3-triazolylidene)-carbazolide ligands by applying a straight-forward intramolecular cyclisation reaction, avoiding hazardous and explosive tertbutylhypochlorite. Furthermore, following a simple deprotonation protocol using only triethylamine as a base, we have been able to synthesise new nickel(II) complexes $\mathbf{4 a , b}$.

In contrast to their imidazolylidene $\mathrm{Ni}$ (II) congeners, which previously have been found to be good polymerisation catalysts, ${ }^{15}$ the $1,2,3$-triazolylidene complexes $\mathbf{4 a , b}$ presented in this work turned out to be moderate catalysts for the cyclisation of carbon dioxide and epoxides to cyclic carbonates. However, it should be pointed out again, that the selectivity of cyclisation $v s$. polymerisation is strongly balanced by electronic and steric effects of the catalysts, as well as the applied pressure of $\mathrm{CO}_{2}$, and even subtle changes in catalyst design can have a large impact. ${ }^{36}$ Nevertheless, these results represent a rare case, in which the replacement of normal by mesoionic carbenes in a catalyst has not led to an increase of its catalytic potential, but to an inversion of selectivity. We are currently investigating the cause of this selectivity switch and further applications of the new carbazole-derived MIC ligands in early transition metal coordination chemistry and photochemistry.

\section{Experimental section}

\section{General remarks}

If not otherwise mentioned, all transformations involving nickel precursors were carried out under inert conditions using the Schlenk technique or an argon-filled glovebox. Organic syntheses were carried out under ambient conditions without taking precautions to exclude moisture or air. Solvents were dried by a MBraun SPS system and stored over activated molecular sieves ( $3 \AA$ ) for at least $24 \mathrm{~h}$. The deuterated solvents $\mathrm{CDCl}_{3}$ and $\mathrm{CD}_{2} \mathrm{Cl}_{2}$ were used as received without any prior drying. IR spectra were recorded at room temperature under inert conditions using a Bruker Vertex 70 with ATR equipment. 
NMR spectra were collected at $298 \mathrm{~K}$ on a Bruker AV-500 or an Ascent 700 spectrometer using regular NMR tubes. All chemical shifts $(\delta)$ are reported in ppm. ${ }^{1} \mathrm{H}$ and ${ }^{13} \mathrm{C}$ chemical shifts were calibrated to residual solvent peaks. ${ }^{15} \mathrm{~N}$ chemical shifts were calibrated to liquid ammonia $\left(\mathrm{NH}_{3}\right)$. Elemental analyses were performed using an Elementar vario microcube instrument at the University of Paderborn. 1,8-Diazido-3,6-di-tertbutylcarbazole $\mathbf{1}^{31}$ and triazolium salt $3 \mathbf{b}^{30}$ were prepared following literature known procedures. All reagents were used as received without further purification.

\section{Synthetic procedures}

3,6-Di-tert-butyl-1,8-bis-(4-(3-chloropropyl)-1,2,3-triazolyl)carbazole (2a). To a mixture of 3,6-di-tert-butyl-carbazole-1,8diazide (867 mg, $2.4 \mathrm{mmol}, 1$ equiv.), 5-chloro-1-pentyne (564 mg, $0.58 \mathrm{~mL}, 5.5 \mathrm{mmol}, 2.3$ equiv.), sodium ascorbate (125 mg, $0.6 \mathrm{mmol}, 0.25$ equiv.) and tris[(1-benzyl-1H-1,2,3triazol-4-yl)methyl]amine (TBTA, $133 \mathrm{mg}, 0.25 \mathrm{mmol}, 0.1$ equiv.) in dichloromethane $(10 \mathrm{~mL})$, tert-butanol $(10 \mathrm{~mL})$ and water $(2 \mathrm{~mL})$ a solution of copper sulfate $(40 \mathrm{mg}, 0.25 \mathrm{mmol}$, 0.1 equiv.) in water $(2 \mathrm{~mL})$ was added. The resulting reaction mixture was stirred at room temperature under an atmosphere of argon for $16 \mathrm{~h}$. The beige-coloured suspension was filtered, and the precipitate washed with $n$-pentane $(2 \times 10 \mathrm{~mL})$. The solid was extracted with dichloromethane $(2 \times 25 \mathrm{~mL})$ and filtered. All volatiles of the filtrate were removed under reduced pressure. The slightly pink-coloured solid was further dried in vacuo to yield the desired product in $70 \%$ yield (953 mg, $1.68 \mathrm{mmol}) .{ }^{1} \mathrm{H} \mathrm{NMR}\left(\mathrm{CDCl}_{3}, 298 \mathrm{~K}, 500 \mathrm{MHz}\right.$, in ppm): 10.82 (s, 1H, Carbazole-NH), 8.16 (d, $J=1.3 \mathrm{~Hz}, 2 \mathrm{H}$, Aryl-H), 8.02 (s, $2 \mathrm{H}$, triazole-5H), $7.60(\mathrm{~d}, J=1.3 \mathrm{~Hz}, 2 \mathrm{H}$, Aryl-H), $3.69(\mathrm{t}, J=6.3$ $\mathrm{Hz}, 4 \mathrm{H},-\mathrm{CH}_{2} \mathrm{Cl}$ ), 3.06 (t, $J=7.3 \mathrm{~Hz}, 4 \mathrm{H}, \mathrm{CH}_{2}$ ), 2.32 (pent, $J=$ $\left.6.3 \mathrm{~Hz}, 4 \mathrm{H}, \mathrm{CH}_{2}\right), 1.52\left(\mathrm{~s}, 18 \mathrm{H}, \mathrm{C}\left(\mathrm{CH}_{3}\right)_{3}\right) ;{ }^{13} \mathrm{C}\left\{{ }^{1} \mathrm{H}\right\} \mathrm{NMR}\left(\mathrm{CDCl}_{3}\right.$, $298 \mathrm{~K}, 125 \mathrm{MHz}$, in ppm): 146.6 (Aryl-C), 143.5 (Aryl-C), 130.3 (Aryl-C), 125.9 (Aryl-C), 121.5 (Aryl-C), 119.3 (Triazolyl-5C), 116.7 (Aryl-CH), 114.6116 .7 (Aryl-CH), $44.4\left(-\mathrm{CH}_{2} \mathrm{Cl}\right), 35.1$ $\left(\mathrm{C}\left(\mathrm{CH}_{3}\right)_{3}\right), 32.1\left(\mathrm{C}\left(\mathrm{CH}_{3}\right)_{3}\right), 31.9\left(\mathrm{CH}_{2}\right), 22.9\left(\mathrm{CH}_{2}\right)$; Hi-Res mass (ESI+) calcd. for $\left[\mathrm{C}_{30} \mathrm{H}_{37} \mathrm{~N}_{7} \mathrm{Cl}_{2}+\mathrm{H}^{+}\right] 566.2566$ found: 566.2567; Elemental analysis calcd. for $\mathrm{C}_{30} \mathrm{H}_{37} \mathrm{~N}_{7} \mathrm{Cl}_{2} \cdot 0.25 \mathrm{CH}_{2} \mathrm{Cl}_{2} \mathrm{C} 61.81$ H 6.46 N 16.68 found C 62.01 H 6.62 N 16.53.

3,6-Di-tert-butyl-1,8-bis-(4,5,6-trihydropyrrolo-1,2,3-triazoliumyl)-carbazole-diiodide (3a). A mixture of 3,6-Di-tert-butyl-1,8bis-(4-(3-chloropropyl)-1,2,3-triazolyl)-carbazole $\quad(932 \mathrm{mg}$, $1.64 \mathrm{mmol}, 1$ equiv.) and potassium iodide (5.46 g, $32.9 \mathrm{mmol}$, 20 equiv.) was heated in acetonitrile $(50 \mathrm{~mL})$ at $90{ }^{\circ} \mathrm{C}$ for $44 \mathrm{~h}$. All volatiles of the reaction mixture were removed under reduced pressure. The remaining solid was extracted with dichloromethane $(3 \times 50 \mathrm{~mL})$ and filtered. The filtrate was concentrated to $20 \mathrm{~mL}$ and added dropwise to a stirred solution of diethylether $(300 \mathrm{~mL})$. The precipitate was filtered off and washed with diethylether $(100 \mathrm{~mL})$ and $n$-pentane $(30 \mathrm{~mL})$. The beige-colored solid was dried in vacuo to yield the desired product in 91\% yield (1.11 g, $1.49 \mathrm{mmol}) .{ }^{1} \mathrm{H} \mathrm{NMR}\left(\mathrm{CD}_{2} \mathrm{Cl}_{2}\right.$, $298 \mathrm{~K}, 500 \mathrm{MHz}$, in ppm): 10.97 (s, 1H, Carbazole-NH), 8.67 (s, $2 \mathrm{~h}$, triazole-5H), 8.43 (d, $J=1.7 \mathrm{~Hz}, 2 \mathrm{H}$, Aryl-H), 7.81 (d, $J=1.7$ $\mathrm{Hz}, 2 \mathrm{H}$, Aryl-H), 4.90 (t, $J=6.3 \mathrm{~Hz}, 4 \mathrm{H}, \mathrm{N}-\mathrm{CH}_{2}$ ), 3.40 (t, $J=7.5$
$\left.\mathrm{Hz}, 4 \mathrm{H}, \mathrm{CH}_{2}\right), 2.96\left(\mathrm{~m}, 8 \mathrm{H}, \mathrm{CH}_{2}\right), 1.50\left(\mathrm{~s}, 18 \mathrm{H}, \mathrm{C}\left(\mathrm{CH}_{3}\right)_{3} ;{ }^{13} \mathrm{C}\right.$ $\left\{{ }^{1} \mathrm{H}\right\} \mathrm{NMR}\left(\mathrm{CD}_{2} \mathrm{Cl}_{2}, 298 \mathrm{~K}, 125 \mathrm{MHz}\right.$, in ppm): 149.2 (Aryl-C), 144.9 (Aryl-C), 133.2 (Aryl-C), 127.3 (triazolium-5C), 126.1 (ArylC), 121.4 (Aryl-CH), 121.2 (Aryl-CH), 119.9(Aryl-C), 52.5 $\left(\mathrm{N}-\mathrm{CH}_{2}\right), 35.4\left(\mathrm{C}\left(\mathrm{CH}_{3}\right)_{3}\right), 31.9\left(\mathrm{C}\left(\mathrm{CH}_{3}\right)_{3}\right), 26.7\left(\mathrm{CH}_{2}\right), 23.9\left(\mathrm{CH}_{2}\right)$; Hi-Res mass (ESI+) calcd. for $\left[\mathrm{C}_{30} \mathrm{H}_{37} \mathrm{~N}_{7}\right]^{2+} 247.6555$; found:

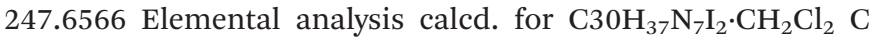
44.62 H 4.71 N 11.75; found: C $44.46 \mathrm{H} 4.88$ N 12.15 .

(3,6-Di-tert-butyl-1,8-bis-(4,5,6-trihydropyrrolo-1,2,3-triazolylidene)-carbazolid) nickel(II) (4a). Triazolium salt 3a (225 mg, $0.3 \mathrm{mmol}, 1$ equiv.) and $\mathrm{Ni}(\mathrm{OAc})_{2} \cdot 4 \mathrm{H}_{2} \mathrm{O}(74.6 \mathrm{mg}, 0.3 \mathrm{mmol}, 1$ equiv.) was dissolved in dry acetonitrile and excess triethylamine (304 mg, $3 \mathrm{mmol}, 0.42 \mathrm{~mL}, 10$ equiv.,) was added. The mixture was sealed and stirred at $82{ }^{\circ} \mathrm{C}$ overnight resulting in the formation of a thick yellow suspension. The solvent was reduced under reduced pressure, and the residue was dissolved in dichloromethane $(20 \mathrm{~mL})$ and filtered through a pad of Celite. The clear orange-red solution was extracted with water and brine, dried over magnesium sulphate and concentrated under reduced pressure to $3 \mathrm{~mL}$. Addition of hexane $(50 \mathrm{~mL})$ cause the precipitation of the desired complex $4 \mathbf{a}$, which was isolated by filtration and dried in air to give $\mathbf{4 a}$ as a free-flowing powder in a yield of $83 \%$. (152 $\mathrm{mg}, 0.249 \mathrm{mmol}$ ) ${ }^{1} \mathrm{H}$ NMR $\left(\mathrm{CD}_{2} \mathrm{Cl}_{2}, 298 \mathrm{~K}, 700 \mathrm{MHz}\right.$, in ppm): 8.24 (s, 2H, Aryl$\mathrm{H}), 8.14$ (s, 2H, Aryl-H), 4.48 (s, 4H, N-CH $\mathrm{CH}_{2}, 3.15$ (s, 4H, $\mathrm{CH}_{2}$ ), $2.74\left(\mathrm{~s}, 4 \mathrm{H}, \mathrm{CH}_{2}\right), 2.18\left(\mathrm{~s}, 3 \mathrm{H}\right.$, acetate- $\left.\mathrm{CH}_{3}\right), 1.50(\mathrm{~s}, 18 \mathrm{H}$, $\left.\mathrm{C}\left(\mathrm{CH}_{3}\right)_{3}\right) ;{ }^{13} \mathrm{C}\left\{{ }^{1} \mathrm{H}\right\} \mathrm{NMR}\left(\mathrm{CD}_{2} \mathrm{Cl}_{2}, 298 \mathrm{~K}, 125 \mathrm{MHz}\right.$, in ppm): 177.7 (acetate- $\mathrm{CO}_{2}$ ) 152.0 (triazolylidene-5C), 145.9 (Aryl-C), 140.8 (Aryl-C), 137.4 (Aryl-C), 127.9 (Aryl-C), 124.0 (Aryl-C),

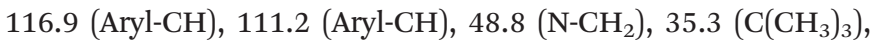
$32.4\left(\mathrm{C}\left(\mathrm{CH}_{3}\right)_{3}\right), 26.9\left(\mathrm{CH}_{2}\right), 25.8\left(\right.$ acetate- $\left.\mathrm{CH}_{3}\right), 25.6\left(\mathrm{CH}_{2}\right)$; HiRes mass (ESI+) calcd. for $\left[\mathrm{C}_{30} \mathrm{H}_{34} \mathrm{~N}_{7} \mathrm{Ni}\right]^{+} 550.2229$; found: 550.2228. Elemental analysis calcd. for $\mathrm{C}_{32} \mathrm{H}_{37} \mathrm{~N}_{7} \mathrm{O}_{2} \mathrm{Ni} \cdot 0.9$ $\mathrm{CH}_{2} \mathrm{Cl}_{2} \mathrm{C} 57.53, \mathrm{H} 5.69, \mathrm{~N} 14.28$; found $\mathrm{C} 57.42, \mathrm{H} 5.81, \mathrm{~N}$ 14.39 .

(3,6-Di-tert-butyl-1,8-bis-(2,4,5,6-tetrahydropyridin-1,2,3-triazolylidene)-carbazolid) nickel(II) (4b). Triazolium salt 3a (233 mg, $0.3 \mathrm{mmol}, 1$ equiv.) and $\mathrm{Ni}(\mathrm{OAc})_{2} \cdot 4 \mathrm{H}_{2} \mathrm{O}(74.6 \mathrm{mg}$, $0.3 \mathrm{mmol}, 1$ equiv.) was dissolved in dry acetonitrile and excess triethylamine ( $304 \mathrm{mg}, 3 \mathrm{mmol}, 0.42 \mathrm{~mL}, 10$ equiv.) was added. The mixture was sealed and stirred at $82{ }^{\circ} \mathrm{C}$ overnight resulting in the formation of an orange solution with a fine white precipitate. The solvent was reduced under reduced pressure, and the residue was dissolved in dichloromethane $(20 \mathrm{~mL})$ and filtered through a pad of Celite. The clear orangered solution was extracted with water and brine, dried over magnesium sulphate and concentrated under reduced pressure to $3 \mathrm{~mL}$. Addition of hexane $(50 \mathrm{~mL})$ cause the precipitation of the desired complex $\mathbf{4 b}$, which was isolated by filtration and dried in air to give $\mathbf{4} \mathbf{b}$ as a free-flowing powder in a yield of 83\%. (159 mg, $0.249 \mathrm{mmol}){ }^{1} \mathrm{H}$ NMR $\left(\mathrm{CD}_{2} \mathrm{Cl}_{2}, 298 \mathrm{~K}\right.$, $700 \mathrm{MHz}$, in ppm): 8.23 (s, 2H, Aryl-H), 8.15 (s, 2H, Aryl-H), 4.49 (s, 4H, N-CH $\left.{ }_{2}\right), 3.26\left(\mathrm{~s}, 4 \mathrm{H}, \mathrm{CH}_{2}\right), 2.15\left(\mathrm{~s}, 4 \mathrm{H}, \mathrm{CH}_{2}\right), 2.08$ $\left(\mathrm{s}, 3 \mathrm{H}\right.$, acetate- $\left.\mathrm{CH}_{3}\right), 1.96\left(\mathrm{~s}, 4 \mathrm{H}, \mathrm{CH}_{2}\right), 1.51\left(\mathrm{~s}, 18 \mathrm{H}, \mathrm{C}\left(\mathrm{CH}_{3}\right)_{3}\right)$; ${ }^{13} \mathrm{C}\left\{{ }^{1} \mathrm{H}\right\} \mathrm{NMR}\left(\mathrm{CD}_{2} \mathrm{Cl}_{2}, 298 \mathrm{~K}, 125 \mathrm{MHz}\right.$, in $\left.\mathrm{ppm}\right): 177.1$ (acetate- $\mathrm{CO}_{2}$ ), 146.9 (triazolyldiene-5C), 145.0 (Aryl-C), 140.7 
(Aryl-C), 137.5 (Aryl-C), 127.9 (Aryl-C), 123.5 (Aryl-C), 116.9 (Aryl-CH), 111.5 (Aryl-CH), $48.8\left(\mathrm{~N}-\mathrm{CH}_{2}\right), 35.3\left(\mathrm{C}\left(\mathrm{CH}_{3}\right)_{3}\right), 32.5$ $\left(\mathrm{C}\left(\mathrm{CH}_{3}\right)_{3}\right), 25.3$ (acetate- $\left.\mathrm{CH}_{3}\right), 24.4\left(\mathrm{CH}_{2}\right), 22.5\left(\mathrm{CH}_{2}\right), 20.8$ $\left(\mathrm{CH}_{2}\right)$; Hi-Res mass (ESI+) calcd. for $\left[\mathrm{C}_{32} \mathrm{H}_{38} \mathrm{~N}_{7} \mathrm{Ni}\right]^{+}$578.2542; found: 578.2578. Elemental analysis calcd. for $\mathrm{C}_{34} \mathrm{H}_{41} \mathrm{~N}_{7}$ $\mathrm{O}_{2} \mathrm{Ni} \cdot 0.5 \mathrm{CH}_{2} \mathrm{Cl}_{2} \mathrm{C} 60.86, \mathrm{H} 6.22, \mathrm{~N}$ 14.40; found $\mathrm{C} 60.79, \mathrm{H}$ 6.48, N 14.18 .

General procedure for the cyclisation to products $5 a-e$. In a GC-vial with a magnetic stir bar a mixture of the epoxide (2.77 mmol, 1000 eq.), the catalyst (2.77 $\mu \mathrm{mol} ; 1$ eq.) and the cocatalyst (2.77 $\mu \mathrm{mol} ; 1 \mathrm{eq}$.) was given in an autoclave. After a pressure of 20 bar of $\mathrm{CO}_{2}$ was applied, the reaction was stirred at $130{ }^{\circ} \mathrm{C}$ for $18 \mathrm{~h}$. The reaction was quenched by cooling with an ice bath and carefully releasing the excess of $\mathrm{CO}_{2}$. Immediately an NMR sample was taken from the mixture, measured and the remaining mixture diluted with $\mathrm{CHCl}_{3}$ and precipitated from $\mathrm{MeOH}$ to isolate eventually formed polycarbonate. Please note that in none of our experiments PC could be precipitated. Epoxide conversion was determined from the integrals in the proton NMR spectra of the reaction mixture. Using the Integrals of the formed cyclic carbonate $I_{\mathrm{CC}}$, polyether $I_{\mathrm{PE}}$ and the residual monomer $I_{\text {Monomer }}$ and the following formula:

$$
\text { Conv. }=\frac{I_{\mathrm{CC}}+I_{\mathrm{PE}}}{I_{\mathrm{CC}}+I_{\mathrm{PE}}+I_{\mathrm{Monomer}}}
$$

CHO. The crude product was analyzed by ${ }^{1} \mathrm{H}$ NMR spectroscopy in deuterated chloroform. Therefore, the determination of the conversions where done by the methanetriyl resonances from cyclohexene oxide ( $\mathrm{dd}, \delta=3.12 \mathrm{ppm})$, polyether linkages (br., $\delta=3.70-3.20 \mathrm{ppm}$ ), and cyclic carbonate (multiplet, $\delta=4.67 \mathrm{ppm}$, cis cyclic carbonate).

GMPE. The crude product was analyzed by ${ }^{1} \mathrm{H}$ NMR spectroscopy in deuterated chloroform. Therefore, the determination of the conversions where done by the methanetriyl resonances from glycidyl methoxyphenyl ether (dd, $\delta=3.36 \mathrm{ppm}$ ), and cyclic carbonate (multiplet, $\delta=5.24 \mathrm{ppm}$, cis cyclic carbonate).

AGE. The crude product was analyzed by ${ }^{1} \mathrm{H}$ NMR spectroscopy in deuterated chloroform. Therefore, the determination of the conversions where done by the methanetriyl resonances from allyl glycidyl ether (dd, $\delta=3.15 \mathrm{ppm}$ ), and cyclic carbonate (multiplets, $\delta=4.81 \mathrm{ppm}$, cis cyclic carbonate).

E5H. The crude product was analyzed by ${ }^{1} \mathrm{H}$ NMR spectroscopy in deuterated chloroform. Therefore, the determination of the conversions where done by the methanetriyl resonances from 1,2-epoxyhex-5-ene ( $\mathrm{dd}, \delta=2.93 \mathrm{ppm}$ ), and cyclic carbonate (multiplet, $\delta=4.72 \mathrm{ppm}$, cis cyclic carbonate).

tBOMC. The crude product was analyzed by ${ }^{1} \mathrm{H}$ NMR spectroscopy in deuterated chloroform. Therefore, the determination of the conversions where done by the epoxide methylene resonances from tert-butyl(oxiran-2-ylmethyl)carbamate (dd, $\delta=2.54 \mathrm{ppm}$, and dd, $\delta=2.72 \mathrm{ppm}$ ), and cyclic carbonate (dd, $\delta=4.28 \mathrm{ppm}$, and dd, $\delta=4.51 \mathrm{ppm}$ ). Several additional resonances could be observed but the substance/substances causing these could not be isolated.
In order to isolate the cyclic carbonate, the solvent was removed under reduced pressure and purified by column chromatography (silica, $\mathrm{CH} / \mathrm{EE}$ ).

Hexahydro-1,3-benzodioxol-2-one (5a). The NMR data obtained agrees with the literature. ${ }^{15,40}{ }^{1} \mathrm{H} \mathrm{NMR}\left(\mathrm{CDCl}_{3}\right.$, $303 \mathrm{~K}, 500 \mathrm{MHz}$, in ppm): $4.67(\mathrm{~m}, 2 \mathrm{H}, \mathrm{CH}), 1.89\left(\mathrm{dd} ; J_{\mathrm{HH}}=5.4\right.$ $\left.\mathrm{Hz},{ }^{3} J_{\mathrm{HH}}=10.8 \mathrm{~Hz}, 4 \mathrm{H}, \mathrm{CH}_{2}\right), 1.61\left(\mathrm{~m}, 2 \mathrm{H}, \mathrm{CH}_{2}\right), 1.43(\mathrm{~m}, 2 \mathrm{H}$, $\left.\mathrm{CH}_{2}\right) ;{ }^{13} \mathrm{C}\left\{{ }^{1} \mathrm{H}\right\}$ NMR $\left(\mathrm{CDCl}_{3}, 303 \mathrm{~K}, 175 \mathrm{MHz}\right.$, in ppm): 155.4 $\left(\mathrm{C}_{\mathrm{q}}\right), 75.8(\mathrm{CH}), 26.9\left(\mathrm{CH}_{2}\right), 19.3\left(\mathrm{CH}_{2}\right)$; Hi-Res mass (ESI+) calcd. for $\left[\mathrm{C}_{8} \mathrm{H}_{15} \mathrm{O}_{2} \mathrm{~N}+\mathrm{H}^{+}\right] 143.0703$ found: 143.0716 .

4-((2-methoxyphenoxy)methyl)-1,3-dioxolan-2-one (5b). The NMR data obtained agrees with the literature. ${ }^{41}{ }^{1} \mathrm{H}$ NMR $\left(\mathrm{CDCl}_{3}, 303 \mathrm{~K}, 500 \mathrm{MHz}\right.$, in ppm): 7.06-6.95 (m, 4H, Aryl-H), $5.00(\mathrm{~m}, 1 \mathrm{H}, \mathrm{CH}), 4.61\left(\mathrm{~m}, 2 \mathrm{H}\right.$, Dioxolane- $\left.\mathrm{CH}_{2}\right), 4.22\left(\mathrm{~d},{ }^{3} \mathrm{~J}_{\mathrm{HH}}=\right.$ $\left.4.3 \mathrm{~Hz}, 2 \mathrm{H}, \mathrm{OCH}_{2}\right), 3.84\left(\mathrm{~s}, 3 \mathrm{H}, \mathrm{OCH}_{3}\right) ;{ }^{13} \mathrm{C}\left\{{ }^{1} \mathrm{H}\right\} \mathrm{NMR}\left(\mathrm{CDCl}_{3}\right.$, $303 \mathrm{~K}, 175 \mathrm{MHz}$, in ppm): 155.8 (Dioxolane- $\mathrm{C}_{\mathrm{q}}$ ), 150.6 (Aryl$\mathrm{C}_{\mathrm{q}}$ ), 147.6 (Aryl- $\left.\mathrm{C}_{\mathrm{q}}\right), 123.6$ (Aryl-CH), 121.2 (Aryl-CH), 117.0 (Aryl-CH), 112.0 (Aryl-CH), 74.6 (Dioxolane-CH), $69.5\left(\mathrm{OCH}_{2}\right)$, 66.5 (Allyl- $\left.\mathrm{CH}_{2}\right), 56.0\left(\mathrm{OCH}_{3}\right)$; Hi-Res mass (ESI+) calcd. for $\left[\mathrm{C}_{8} \mathrm{H}_{15} \mathrm{O}_{2} \mathrm{~N}+\mathrm{H}^{+}\right] 224.0685$ found: 224.0688 .

4-((Allyloxy)methyl)-1,3-dioxolan-2-one (5c). The NMR data obtained agrees with the literature. ${ }^{42}{ }^{1} \mathrm{H} \mathrm{NMR}\left(\mathrm{CDCl}_{3}, 303 \mathrm{~K}\right.$, $500 \mathrm{MHz}$, in ppm): 5.86 (m, 1H, Allyl-CH), 5.28 (m, 1H, Allyl$\mathrm{CH}_{2}$ ), 5.22 (m, Allyl- $\mathrm{CH}_{2}$ ), 4.81 (m, 1H, Dioxolane-CH), 4.49 $\left(\mathrm{dd},{ }^{2} J_{\mathrm{HH}, \text { trans }}=8.4 \mathrm{~Hz},{ }^{3} J_{\mathrm{HH}}=8.4 \mathrm{~Hz}, 1 \mathrm{H}\right.$, Dioxolane- $\left.\mathrm{CH}_{2}\right), 4.39$ $\left(\mathrm{dd},{ }^{2} J_{\mathrm{HH}, \text { cis }}=6.1 \mathrm{~Hz},{ }^{3} J_{\mathrm{HH}}=8.4 \mathrm{~Hz}, 1 \mathrm{H}\right.$, Dioxolane- $\mathrm{CH}_{2}$ ), 4.05 $\left(\mathrm{m}, 2 \mathrm{H}\right.$, Allyl-OCH $\left.\mathrm{H}_{2}\right), 3.68\left(\mathrm{~m}, 2 \mathrm{H}\right.$, Dioxolane- $\left.\mathrm{CH}_{2}\right) ;{ }^{13} \mathrm{C}\left\{{ }^{1} \mathrm{H}\right\}$ NMR ( $\mathrm{CDCl}_{3}, 303 \mathrm{~K}, 175 \mathrm{MHz}$, in ppm): $155.0\left(\mathrm{C}_{\mathrm{q}}\right), 133.8$ (Allyl$\mathrm{CH}$ ), 118.0 (Allyl-CH${ }_{2}$ ), 75.1 (Dioxolane-CH), 72.7 (Allyl-OCH $\mathrm{OCH}_{2}$ ), 69.0 (Dioxolane- $\mathrm{CH}_{2}$ ), 66.4 (Dioxolane- $\left.\mathrm{OCH}_{2}\right)$.

4-(But-3-en-1-yl)-1,3-dioxolan-2-one (5d). The NMR data obtained agrees with the literature. ${ }^{43}{ }^{1} \mathrm{H} \mathrm{NMR}\left(\mathrm{CDCl}_{3}, 303 \mathrm{~K}\right.$, $500 \mathrm{MHz}$, in ppm): 5.78 (m, 1H, Allyl-CH), 5.07 (m, 2H, Allyl$\left.\mathrm{CH}_{2}\right), 4.72\left(\mathrm{~m}, 1 \mathrm{H}\right.$, Dioxolane-CH), $4.52\left(\mathrm{dd},{ }^{2} J_{\mathrm{HH}, \text { trans }}=7.9 \mathrm{~Hz}\right.$, ${ }^{3} J_{\mathrm{HH}}=8.4 \mathrm{~Hz}, 1 \mathrm{H}$, Dioxolane- $\left.\mathrm{CH}_{2}\right), 4.07\left(\mathrm{dd},{ }^{2} J_{\mathrm{HH}, \text { cis }}=7.2 \mathrm{~Hz}\right.$, ${ }^{3} J_{\mathrm{HH}}=8.5 \mathrm{~Hz}, 1 \mathrm{H}$, Dioxolane- $\left.\mathrm{CH}_{2}\right), 1.61\left(\mathrm{~m}, 2 \mathrm{H}, \mathrm{CH}_{2}\right), 2.22(\mathrm{~m}$, 2H, $\left.\mathrm{CH}_{2}\right)$; 2.00-1.70 (m, 2H, $\left.\mathrm{CH}_{2}\right) ;{ }^{13} \mathrm{C}\left\{{ }^{1} \mathrm{H}\right\} \mathrm{NMR}\left(\mathrm{CDCl}_{3}, 303 \mathrm{~K}\right.$, $175 \mathrm{MHz}$, in ppm): $155.0\left(\mathrm{C}_{\mathrm{q}}\right), 136.2$ (Allyl-CH), 116.6 (Allyl$\mathrm{CH}_{2}$ ), 75.1 (Dioxolane-CH), $72.7\left(\right.$ Allyl- $\left.\mathrm{OCH}_{2}\right), 69.0$ (Dioxolane$\mathrm{CH}_{2}$ ), 66.4 (Dioxolane- $\mathrm{OCH}_{2}$ ).

tert-Butyl ((2-oxo-1,3-dioxolan-4-yl)methyl)carbamate (5e). The NMR data obtained agrees with the literature. ${ }^{44}{ }^{1} \mathrm{H}$ NMR $\left(\mathrm{CDCl}_{3}, 303 \mathrm{~K}, 500 \mathrm{MHz}\right.$, in ppm): 5.03 (br., 1H, NH), 4.80 (m, $1 \mathrm{H}, \mathrm{CH}), 4.49\left(\mathrm{dd},{ }^{2} J_{\mathrm{HH}, \text { trans }}=8.8 \mathrm{~Hz},{ }^{3} J_{\mathrm{HH}}=8.8 \mathrm{~Hz}, 1 \mathrm{H}\right.$, Dioxolane- $\left.\mathrm{CH}_{2}\right), 4.26\left(\mathrm{dd},{ }^{2} J_{\mathrm{HH}, \text { cis }}=6.8 \mathrm{~Hz},{ }^{3} J_{\mathrm{HH}}=8.8 \mathrm{~Hz}, 1 \mathrm{H}\right.$, Dioxolane- $\mathrm{CH}_{2}$ ), $3.47\left(\mathrm{dd},{ }^{3} J_{\mathrm{HH}}=6.2 \mathrm{~Hz},{ }^{4} J_{\mathrm{HH}}=4.4 \mathrm{~Hz}, 2 \mathrm{H}\right.$, $\left.\mathrm{NCH}_{2}\right), 1.43$ (s, 9H, C( $\left.\left(\mathrm{CH}_{3}\right)_{3}\right) ;{ }^{13} \mathrm{C}\left\{{ }^{1} \mathrm{H}\right\} \mathrm{NMR}\left(\mathrm{CDCl}_{3}, 303 \mathrm{~K}\right.$, $175 \mathrm{MHz}$, in ppm): 156.4 (Dioxolane- $\mathrm{C}_{\mathrm{q}}$ ), 154.8 (Carbamate$\left.\mathrm{C}_{\mathrm{q}}\right), 80.6\left(\mathrm{C}\left(\mathrm{CH}_{3}\right)_{3}\right) ; 75.9(\mathrm{CH}), 66.8$ (Dioxolane- $\left.\mathrm{CH}_{2}\right), 42.3$ $\left(\mathrm{NCH}_{2}\right), 28.3\left(\mathrm{C}\left(\mathrm{CH}_{3}\right)_{3}\right)$; Hi-Res mass (ESI+) calcd. for $\left[\mathrm{C}_{8} \mathrm{H}_{15} \mathrm{O}_{2} \mathrm{~N}+\mathrm{Na}^{+}\right] 240.0842$ found: 240.0846 .

$\boldsymbol{O}$-tert-Butyl- $\boldsymbol{N}$-allylcarbamate. The synthesis was performed after a procedure of Teerawutgulrag and co-workers. ${ }^{45} \mathrm{~A}$ solution of allyl amine (3.00 g, $52.6 \mathrm{mmol}, 1$ equiv.) and triethyl amine (9.5 mL, $68.0 \mathrm{mmol}, 1.3$ equiv.) in dry DCM (10 mL) was cooled to $0^{\circ} \mathrm{C}$. After addition of di-tert-butyl decarbonate 
(14.6 $\mathrm{mL}, 68.0 \mathrm{mmol}, 1.3$ equiv.) in portions, the mixture was stirred at RT over $18 \mathrm{~h}$. The mixture was washed with $\mathrm{NaOH}$ (10 weight\%, $20 \mathrm{~mL}$ ) and the water layer extracted with ethyl acetate $(3 \times 50 \mathrm{~mL})$. After the combined organic layers were dried over $\mathrm{Na}_{2} \mathrm{SO}_{4}$, the solvent was removed and the crude product purified by column chromatography (silica, $n$-hexane/ethyl acetate $\left.9: 1, R_{\mathrm{f}}=0.58\right)$ to obtain a colorless solid with $85 \%$ yield. (44.7 mmol, $7.03 \mathrm{~g}){ }^{1} \mathrm{H}$ NMR $\left(\mathrm{CDCl}_{3}\right.$, $303 \mathrm{~K}, 500 \mathrm{MHz}$, in ppm): 5.84 (m, 1H, Allyl-CH), 5.18 (m, 1H, Allyl- $\mathrm{CH}_{2}$ ), 5.11 (m, 1H, Allyl- $\mathrm{CH}_{2}$ ), 4.75 (br., $\left.1 \mathrm{H}, \mathrm{NH}\right), 3.74$ (s, 2H, $\left.\mathrm{NCH}_{2}\right), 1.45\left(\mathrm{~s}, 9 \mathrm{H}, \mathrm{C}\left(\mathrm{CH}_{3}\right)_{3}\right) ;{ }^{13} \mathrm{C}\left\{{ }^{1} \mathrm{H}\right\}$ NMR $\left(\mathrm{CDCl}_{3}\right.$, $303 \mathrm{~K}, 175 \mathrm{MHz}$, in ppm): $155.9\left(\mathrm{C}_{\mathrm{q}}\right), 135.1$ (Allyl-CH), 115.8 (Allyl- $\left.\mathrm{CH}_{2}\right), 79.5\left(\mathrm{C}\left(\mathrm{CH}_{3}\right)_{3}\right), 43.2\left(\mathrm{NCH}_{2}\right), 28.5\left(\mathrm{C}\left(\mathrm{CH}_{3}\right)_{3}\right)$; HiRes mass (ESI+) calcd. for $\left[\mathrm{C}_{8} \mathrm{H}_{15} \mathrm{O}_{2} \mathrm{~N}+\mathrm{Na}^{+}\right] 180.1000$ found: 180.1000 .

O-tert-Butyl- $\mathrm{N}$-(oxiran-2-ylmethyl) carbamate (tBOMC). The synthesis was performed after a procedure of Teerawutgulrag and co-workers. ${ }^{45}$ To a cooled solution of $\mathrm{O}$-tert-butyl- $\mathrm{N}$-allylcarbamate $(10.00 \mathrm{~g}, 63.6 \mathrm{mmol}, 1$ equiv.) in dichloro-methane $(500 \mathrm{~mL})$ at $0{ }^{\circ} \mathrm{C}$ was meta-chlorperbenzoic acid $(44.15 \mathrm{~g}$, $50-55 \%, 127.2 \mathrm{mmol}, 2.0$ equiv.) in portions. The mixture was stirred at RT for $18 \mathrm{~h}$ before washed with saturated sodium sulfite solution $(2 \times 130 \mathrm{~mL})$ and saturated sodium bicarbonate solution $(2 \times 150 \mathrm{~mL})$. The water layers were extracted with ethyl acetate $(3 \times 125 \mathrm{~mL})$, the combined organic layers dried over $\mathrm{Na}_{2} \mathrm{SO}_{4}$ and the solvent removed under reduced pressure. The crude product was purified by column chromatography (silica, $n$-hexane/ethyl acetate $4: 1$, $\left.R_{\mathrm{f}}=0.33\right)$ to yield in $81 \%$ of a slightly yellow oil. $(51.5 \mathrm{mmol}$, $8.92 \mathrm{~g}){ }^{1} \mathrm{H}$ NMR $\left(\mathrm{CDCl}_{3}, 303 \mathrm{~K}, 500 \mathrm{MHz}\right.$, in ppm): 4.81 (br., $1 \mathrm{H}, \mathrm{NH}), 3.47$ (br, 1H, N-CH$\left.{ }_{2}\right), 3.18$ (m, 1H, Epoxide- $\mathrm{CH}$ ), 3.05 (br., $1 \mathrm{H}, \mathrm{NCH}_{2}$ ), $2.75\left(\mathrm{dd},{ }^{2} J_{\mathrm{HH}}=4.7 \mathrm{~Hz},{ }^{3} J_{\mathrm{HH}, \text { trans }}=4.2\right.$ $\mathrm{Hz}, 1 \mathrm{H}$, Epoxide- $\left.\mathrm{CH}_{2}\right), 2.57\left(\mathrm{dd},{ }^{2} J_{\mathrm{HH}}=4.8 \mathrm{~Hz},{ }^{3} J_{\mathrm{HH}, c i s}=2.7\right.$ $\mathrm{Hz}, \quad 1 \mathrm{H}$, Allyl- $\left.\mathrm{CH}_{2}\right), 1.42$ (s, 9H, C( $\left.\left(\mathrm{CH}_{3}\right)_{3}\right) .{ }^{13} \mathrm{C}\left\{{ }^{1} \mathrm{H}\right\}$ NMR $\left(\mathrm{CDCl}_{3}, 303 \mathrm{~K}, 175 \mathrm{MHz}\right.$, in ppm): $155.9\left(\mathrm{C}_{\mathrm{q}}\right), 79.6\left(\mathrm{C}\left(\mathrm{CH}_{3}\right)_{3}\right)$, 50.9 (Epoxide- $\mathrm{CH}), 45.1\left(\mathrm{NCH}_{2}\right), 41.8\left(\right.$ Epoxide- $\left.\mathrm{CH}_{2}\right), 28.5$ $\left(\mathrm{C}\left(\mathrm{CH}_{3}\right)_{3}\right)$; Hi-Res mass (ESI+) calcd. for $\left[\mathrm{C}_{8} \mathrm{H}_{15} \mathrm{O}_{2} \mathrm{~N}+\mathrm{Na}^{+}\right]$ 196.0944 found: 196.0950 .

\section{Conflicts of interest}

There are no conflicts to declare.

\section{Acknowledgements}

We are grateful to the Daimler and Benz Foundation, to the Fonds der Chemischen Industrie, to the Young Academy of the North Rhine-Westphalian Academy of Sciences, Humanities, and the Arts, the University of Paderborn and the University of Innsbruck for funding of this work. Prof. Dr Matthias Bauer and Prof. Dr Thomas Kühne are acknowledged for helpful discussions.

\section{Notes and references}

1 E. Peris and R. H. Crabtree, Chem. Soc. Rev., 2018, 47, 1959-1968.

2 M. Fritz and S. Schneider, in Catalytic, materials, biological and medical applications, ed. A. Bhagi-Damodaran, Springer International Publishing, Cham, 2019, vol. 182, pp. 1-36.

3 (a) S. Schneider, J. Meiners and B. Askevold, Eur. J. Inorg. Chem., 2012, 2012, 412-429; (b) L. Alig, M. Fritz and S. Schneider, Chem. Rev., 2019, 119, 2681-2751; (c) M. R. Mills, C. L. Barnes and W. H. Bernskoetter, Inorg. Chem., 2018, 57, 1590-1597.

4 (a) D. Delony, M. Kinauer, M. Diefenbach, S. Demeshko, C. Würtele, M. C. Holthausen and S. Schneider, Angew. Chem., Int. Ed., 2019, 58, 10971-10974; (b) J. Abbenseth and S. Schneider, Z. Anorg. Allg. Chem., 2020, 55, 1690; (c) M. Kinauer, M. Diefenbach, H. Bamberger, S. Demeshko, E. J. Reijerse, C. Volkmann, C. Würtele, J. van Slageren, B. de Bruin, M. C. Holthausen and S. Schneider, Chem. Sci., 2018, 9, 4325-4332; (d) F. Schendzielorz, M. Finger, J. Abbenseth, C. Würtele, V. Krewald and S. Schneider, Angew. Chem., Int. Ed., 2019, 58, 830-834; (e) F. Schneck, M. Finger, M. Tromp and S. Schneider, Chem. - Eur. J., 2017, 23, 33-37; (f) F. Schneck, F. Schendzielorz, N. Hatami, M. Finger, C. Würtele and S. Schneider, Angew. Chem., Int. Ed., 2018, 57, 14482-14487; $(g)$ G. A. Silantyev, M. Förster, B. Schluschaß, J. Abbenseth, C. Würtele, C. Volkmann, M. C. Holthausen and S. Schneider, Angew. Chem., Int. Ed., 2017, 56, 5872-5876; (h) R. S. van Alten, F. Wätjen, S. Demeshko, A. J. M. Miller, C. Würtele, I. Siewert and S. Schneider, Eur. J. Inorg. Chem., 2020, 1, 490; (i) T. Kurogi, B. Pinter and D. J. Mindiola, Organometallics, 2018, 37, 3385-3388; ( $j$ ) U. J. Kilgore, X. Yang, J. Tomaszewski, J. C. Huffman and D. J. Mindiola, Inorg. Chem., 2006, 45, 10712-10721; (k) U. J. Kilgore, J. Tomaszewski, H. Fan, J. C. Huffman and D. J. Mindiola, Organometallics, 2007, 26, 6132-6138; (l) U. J. Kilgore, C. A. Sengelaub, H. Fan, J. Tomaszewski, J. A. Karty, M.-H. Baik and D. J. Mindiola, Organometallics, 2009, 28, 843-852; (m) B. C. Bailey, J. C. Huffman, D. J. Mindiola, W. Weng and O. V. Ozerov, Organometallics, 2005, 24, 1390-1393; (n) D. Adhikari, S. Mossin, F. Basuli, B. R. Dible, M. Chipara, H. Fan, J. C. Huffman, K. Meyer and D. J. Mindiola, Inorg. Chem., 2008, 47, 10479-10490; (o) T. Kurogi, M. E. Miehlich, D. Halter and D. J. Mindiola, Organometallics, 2018, 37, 165-167; ( $p$ ) T. Kurogi, M. Kamitani, B. C. Manor, P. J. Carroll and D. J. Mindiola, Organometallics, 2017, 36, 74-79; (q) T. Kurogi, P. J. Carroll and D. J. Mindiola, J. Am. Chem. Soc., 2016, 138, 4306-4309; (r) M. Kamitani, K. Searles, C.-H. Chen, P. J. Carroll and D. J. Mindiola, Organometallics, 2015, 34, 2558-2566; $(s)$ A. R. Fout, B. C. Bailey, D. M. Buck, H. Fan, J. C. Huffman, M.-H. Baik and D. J. Mindiola, Organometallics, 2010, 29, 5409-5422; (t) S. Mossin, B. L. Tran, D. Adhikari, M. Pink, F. W. Heinemann, J. Sutter, R. K. Szilagyi, K. Meyer and 
D. J. Mindiola, J. Am. Chem. Soc., 2012, 134, 13651-13661; (u) D. Adhikari, M. Pink and D. J. Mindiola, Organometallics, 2009, 28, 2072-2077; (v) S.-Y. Baek, T. Kurogi, D. Kang, M. Kamitani, S. Kwon, D. P. Solowey, C.-H. Chen, M. Pink, P. J. Carroll, D. J. Mindiola and M.-H. Baik, J. Am. Chem. Soc., 2017, 139, 12804-12814; (w) M. Schlagbauer, F. Kallmeier, T. Irrgang and R. Kempe, Angew. Chem., Int. Ed., 2020, 59, 1485-1490.

5 (a) D. Benito-Garagorri and K. Kirchner, Acc. Chem. Res., 2008, 41, 201-213; (b) W. Eder, B. Stöger and K. Kirchner, Chem. Mon., 2019, 150, 1235-1240; (c) J. He, N. W. Waggoner, S. G. Dunning, A. Steiner, V. M. Lynch and S. M. Humphrey, Angew. Chem., Int. Ed., 2016, 55, 12351-12355; (d) D. Himmelbauer, M. Mastalir, B. Stöger, L. F. Veiros, M. Pignitter, V. Somoza and K. Kirchner, Inorg. Chem., 2018, 57, 7925-7931; (e) G. van Koten, in Organometallic Pincer Chemistry, ed. G. van Koten and D. Milstein, Springer, Berlin, Heidelberg, 2013, vol. 40, pp. 1-20; (f) Organometallic Pincer Chemistry, ed. G. van Koten and D. Milstein, Springer, Berlin, Heidelberg, 2013, vol. 40; (g) S. K. Gibbons, Z. Xu, R. P. Hughes, D. S. Glueck and A. L. Rheingold, Organometallics, 2018, 37, 2159-2166.

6 G. M. Adams and A. S. Weller, Coord. Chem. Rev., 2018, 355, 150-172.

7 (a) C. Romain, D. Specklin, K. Miqueu, J.-M. Sotiropoulos, C. Fliedel, S. Bellemin-Laponnaz and S. Dagorne, Organometallics, 2015, 34, 4854-4863; (b) C. Romain, B. Heinrich, S. B. Laponnaz and S. Dagorne, Chem. Commun., 2012, 48, 2213-2215; (c) C. Romain, S. Choua, J.-P. Collin, M. Heinrich, C. Bailly, L. Karmazin-Brelot, S. Bellemin-Laponnaz and S. Dagorne, Inorg. Chem., 2014, 53, 7371-7376; (d) U. J. Kilgore, X. Yang, J. Tomaszewski, J. C. Huffman and D. J. Mindiola, Inorg. Chem., 2006, 45, 10712-10721; (e) W. Kai, H. Qian, D. Liu and Z. Ye, J. Saudi Chem. Soc., 2019, 23, 274-283; $(f)$ C. F. Harris, C. S. Kuehner, J. Bacsa and J. D. Soper, Angew. Chem., Int. Ed., 2018, 57, 1311-1315; (g) C. F. Harris, M. B. Bayless, N. P. van Leest, Q. J. Bruch, B. N. Livesay, J. Bacsa, K. I. Hardcastle, M. P. Shores, B. de Bruin and J. D. Soper, Inorg. Chem., 2017, 56, 12421-12435; (h) L. Gravogl, F. W. Heinemann, D. Munz and K. Meyer, Inorg. Chem., 2020, 59(8), 5632-5645; (i) C. Gandara, C. Philouze, O. Jarjayes and F. Thomas, Inorg. Chim. Acta, 2018, 482, 561-566; $(j)$ E. Despagnet-Ayoub, M. K. Takase, J. A. Labinger and J. E. Bercaw, J. Am. Chem. Soc., 2015, 137, 10500-10503; $(k)$ J. D. Carter and Y. Schrodi, Organometallics, 2020, 39, 378-382; (l) E. Borré, G. Dahm, A. Aliprandi, M. Mauro, S. Dagorne and S. BelleminLaponnaz, Organometallics, 2014, 33, 4374-4384; (m) M. Baltrun, F. A. Watt, R. Schoch, C. Wölper, A. G. Neuba and S. Hohloch, Dalton Trans., 2019, 48, 14611-14625; (n) M. Baltrun, F. A. Watt, R. Schoch and S. Hohloch, Organometallics, 2019, 38, 3719-3729; (o) S. Liu, J. I. Amaro-Estrada, M. Baltrun, I. Douair, R. Schoch, L. Maron and S. Hohloch, Organometallics, 2021, 40, 107-118; ( $p$ ) F. R. Neururer, S. Liu, D. Leitner,
M. Baltrun, K. R. Fisher, H. Kopacka, K. Wurst, L. J. Daumann, D. Munz and S. Hohloch, Inorg. Chem., 2021, 60, 15421-15434.

8 A. L. Speelman, K. L. Skubi, B. Q. Mercado and P. L. Holland, Inorg. Chem., 2021, 60, 1965-1974.

9 (a) J. M. Darmon, R. P. Yu, S. P. Semproni, Z. R. Turner, S. C. E. Stieber, S. DeBeer and P. J. Chirik, Organometallics, 2014, 33, 5423-5433; (b) L. A. Fredin, M. Pápai, E. Rozsályi, G. Vankó, K. Wärnmark, V. Sundström and P. Persson, J. Phys. Chem. Lett., 2014, 5, 2066-2071; (c) Y. Liu, T. Harlang, S. E. Canton, P. Chábera, K. Suárez-Alcántara, A. Fleckhaus, D. A. Vithanage, E. Göransson, A. Corani, R. Lomoth, V. Sundström and K. Wärnmark, Chem. Commun., 2013, 49, 6412-6414; (d) K. Magra, E. Domenichini, A. Francés-Monerris, C. Cebrián, M. Beley, M. Darari, M. Pastore, A. Monari, X. Assfeld, S. Haacke and P. C. Gros, Inorg. Chem., 2019, 58, 5069-5081; (e) L. Maron and D. Bourissou, Organometallics, 2009, 28, 3686-3690; $(f)$ T. H. T. Myren, A. M. Lilio, C. G. Huntzinger, J. W. Horstman, T. A. Stinson, T. B. Donadt, C. Moore, B. Lama, H. H. Funke and O. R. Luca, Organometallics, 2019, 38, 1248-1253; (g) D. Pugh, J. A. Wright, S. Freeman and A. A. Danopoulos, Dalton Trans., 2006, 775-782; (h) S. M. Rummelt, J. M. Darmon, R. P. Yu, P. Viereck, T. P. Pabst, Z. R. Turner, G. W. Margulieux, S. Gu and P. J. Chirik, Organometallics, 2019, 38, 3159-3168; (i) M. Sheng, N. Jiang, S. Gustafson, B. You, D. H. Ess and Y. Sun, Dalton Trans., 2015, 44, 16247-16250; (j) B. Yang and D. G. Truhlar, Organometallics, 2018, 37, 3917-3927; (k) R. P. Yu, J. M. Darmon, J. M. Hoyt, G. W. Margulieux, Z. R. Turner and P. J. Chirik, ACS Catal., 2012, 2, 17601764; (l) R. P. Yu, J. M. Darmon, C. Milsmann, G. W. Margulieux, S. C. E. Stieber, S. DeBeer and P. J. Chirik, J. Am. Chem. Soc., 2013, 135, 13168-13184; (m) P. Zimmer, L. Burkhardt, A. Friedrich, J. Steube, A. Neuba, R. Schepper, P. Müller, U. Flörke, M. Huber, S. Lochbrunner and M. Bauer, Inorg. Chem., 2018, 57, 360373; (n) P. Zimmer, L. Burkhardt, R. Schepper, K. Zheng, D. Gosztola, A. Neuba, U. Flörke, C. Wölper, R. Schoch, W. Gawelda, S. E. Canton and M. Bauer, Eur. J. Inorg. Chem., 2018, 2018, 5203-5214; (o) L. C. Tolley, I. Strydom, W. J. Louw, M. A. Fernandes, D. I. Bezuidenhout and G. Guisado-Barrios, ACS Omega, 2019, 4, 6360-6374; ( $p$ ) P. Dierks, A. Kruse, O. S. Bokareva, M. J. Al-Marri, J. Kalmbach, M. Baltrun, A. Neuba, R. Schoch, S. Hohloch, K. Heinze, M. Seitz, O. Kühn, S. Lochbrunner and M. Bauer, Chem. Commun., 2021, 57, 6640-6643.

10 (a) M. Bauer, J. Steube, A. Päpcke, O. Bokareva, T. Reuter, S. Demeshko, R. Schoch, S. Hohloch, F. Meyer, K. Heinze, O. Kühn and S. Lochbrunner, Res. Square, ver. 1., 2020, DOI: 10.21203/rs.3.rs-64316/v1; (b) A. Sattler and G. Parkin, J. Am. Chem. Soc., 2012, 134, 2355-2366.

11 (a) N. Grüger, L.-I. Rodríguez, H. Wadepohl and L. H. Gade, Inorg. Chem., 2013, 52, 2050-2059; (b) L. Gade, H. Wadepohl and J. Ott, Angew. Chem., Int. Ed., 2020, 59, 9448-9452; (c) K. R. D. Johnson and P. G. Hayes, 
Organometallics, 2009, 28, 6352-6361; (d) J. Higuchi, S. Kuriyama, A. Eizawa, K. Arashiba, K. Nakajima and Y. Nishibayashi, Dalton Trans., 2018, 47, 1117-1121; (e) L. S. Merz, C. K. Blasius, H. Wadepohl and L. H. Gade, Inorg. Chem., 2019, 58, 6102-6113; $(f)$ J. C. Ott, C. K. Blasius, H. Wadepohl and L. H. Gade, Inorg. Chem., 2018, 57, 3183-3191; (g) J. C. Ott, H. Wadepohl, M. Enders and L. H. Gade, J. Am. Chem. Soc., 2018, 140, 17413-17417.

12 (a) B. Wucher, M. Moser, S. A. Schumacher, F. Rominger and D. Kunz, Angew. Chem., 2009, 121, 4481-4485; (b) M. Moser, B. Wucher, D. Kunz and F. Rominger, Organometallics, 2007, 26, 1024-1030; (c) E. Jürgens, K. N. Buys, A.-T. Schmidt, S. K. Furfari, M. L. Cole, M. Moser, F. Rominger and D. Kunz, New J. Chem., 2016, 40, 9160-9169; (d) T. Maulbetsch and D. Kunz, Angew. Chem., Int. Ed., 2021, 60, 2007-2012.

13 (a) E. Jürgens, O. Back, J. J. Mayer, K. Heinze and D. Kunz, Z. Naturforsch., B: J. Chem. Sci., 2016, 71, 1011-1018; (b) E. Jürgens, B. Wucher, F. Rominger, K. W. Törnroos and D. Kunz, Chem. Commun., 2015, 51, 1897-1900; (c) A. Seyboldt, B. Wucher, M. Alles, F. Rominger, C. Maichle-Mössmer and D. Kunz, J. Organomet. Chem., 2015, 775, 202-208; (d) Y. Tian, E. Jürgens and D. Kunz, Chem. Commun., 2018, 54, 11340-11343; (e) Y. Tian, E. Jürgens, K. Mill, R. Jordan, T. Maulbetsch and D. Kunz, ChemCatChem, 2019, 11, 4028-4035; (f) Y. Tian, T. Maulbetsch, R. Jordan, K. W. Törnroos and D. Kunz, Organometallics, 2020, 39, 1221-1229.

14 A. Seyboldt, B. Wucher, S. Hohnstein, K. Eichele, F. Rominger, K. W. Törnroos and D. Kunz, Organometallics, 2015, 34, 2717-2725.

15 T.-Y. Lee, Y.-J. Lin, Y.-Z. Chang, L.-S. Huang, B.-T. Ko and J.-H. Huang, Organometallics, 2017, 36, 291-297.

16 (a) J. A. Garden, A. J. P. White and C. K. Williams, Dalton Trans., 2017, 46, 2532-2541; (b) J. Hessevik, R. Lalrempuia, H. Nsiri, K. W. Törnroos, V. R. Jensen and E. Le Roux, Dalton Trans., 2016, 45, 14734-14744; (c) K. Nakano, K. Kobayashi and K. Nozaki, J. Am. Chem. Soc., 2011, 133, 10720-10723; (d) T. Ohkawara, K. Suzuki, K. Nakano, S. Mori and K. Nozaki, J. Am. Chem. Soc., 2014, 136, 1072810735; (e) C. C. Quadri, R. Lalrempuia, J. Hessevik, K. W. Törnroos and E. Le Roux, Organometallics, 2017, 36, 4477-4489; $(f)$ C. C. Quadri and E. Le Roux, Dalton Trans., 2014, 43, 4242-4246.

17 (a) J. M. Aizpurua, M. Sagartzazu-Aizpurua and Z. Monasterio, in Chemistry of 1,2,3-triazoles, ed. W. Dehaen and B. Abarca, Springer, Cham, 2015, vol. 40, pp. 211-267; (b) Chemistry of 1,2,3-triazoles, ed. W. Dehaen and B. Abarca, Springer, Cham, 2015, vol. 40; (c) S. C. Sau, P. K. Hota, S. K. Mandal, M. Soleilhavoup and G. Bertrand, Chem. Soc. Rev., 2020, 49, 1233-1252; (d) D. Schweinfurth, L. Hettmanczyk, L. Suntrup and B. Sarkar, Z. Anorg. Allg. Chem., 2017, 643, 554-584; (e) G. Guisado-Barrios, M. Soleilhavoup and G. Bertrand, Acc. Chem. Res., 2018, 51, 3236-3244; (f) A. J. Mantanona, D. R. Tolentino, K. S. Cay, M. Gembicky, R. Jazzar, G. Bertrand and J. D. Rinehart,
Dalton Trans., 2020, 49, 2426-2430; $(g)$ Á. Vivancos, C. Segarra and M. Albrecht, Chem. Rev., 2018, 118, 94939586; (h) S. Hohloch, D. Scheiffele and B. Sarkar, Eur. J. Inorg. Chem., 2013, 2013, 3956-3965; (i) S. Hohloch, C.-Y. Su and B. Sarkar, Eur. J. Inorg. Chem., 2011, 2011, 3067-3075; (j) D. Munz, Organometallics, 2018, 37, 275-289.

18 S. Hohloch, B. Sarkar, L. Nauton, F. Cisnetti and A. Gautier, Tetrahedron Lett., 2013, 54, 1808-1812.

19 (a) L. Suntrup, S. Klenk, J. Klein, S. Sobottka and B. Sarkar, Inorg. Chem., 2017, 56, 5771-5783; (b) S. Klenk, L. Suntrup and B. Sarkar, Nachr. Chem., 2018, 66, 717-721; (c) S. Klenk, S. Rupf, L. Suntrup, M. van der Meer and B. Sarkar, Organometallics, 2017, 36, 2026-2035; (d) S. Hohloch, L. Suntrup and B. Sarkar, Inorg. Chem. Front., 2016, 3, 67-77; (e) S. Hohloch, L. Hettmanczyk and B. Sarkar, Eur. J. Inorg. Chem., 2014, 2014, 3164-3171; (f) L. Hettmanczyk, S. J. P. Spall, S. Klenk, M. van der Meer, S. Hohloch, J. A. Weinstein and B. Sarkar, Eur. J. Inorg. Chem., 2017, 2017, 2112-2121; (g) L. Hettmanczyk, D. Schulze, L. Suntrup and B. Sarkar, Organometallics, 2016, 35, 3828-3836; (h) L. Hettmanczyk, S. Manck, C. Hoyer, S. Hohloch and B. Sarkar, Chem. Commun., 2015, 51, 10949-10952; (i) L. Suntrup, F. Stein, G. Hermann, M. Kleoff, M. Kuss-Petermann, J. Klein, O. S. Wenger, J. C. Tremblay and B. Sarkar, Inorg. Chem., 2018, 57, 1397313984; $(j)$ M. van der Meer, E. Glais, I. Siewert and B. Sarkar, Angew. Chem., Int. Ed., 2015, 54, 13792-13795; (k) M. Rigo, L. Hettmanczyk, F. J. L. Heutz, S. Hohloch, M. Lutz, B. Sarkar and C. Müller, Dalton Trans., 2016, 46, 86-95.

20 L. Suntrup, S. Hohloch and B. Sarkar, Chem. - Eur. J., 2016, 22, 18009-18018.

21 S. Hohloch, L. Suntrup and B. Sarkar, Organometallics, 2013, 32, 7376-7385.

22 S. Hohloch, S. Kaiser, F. L. Duecker, A. Bolje, R. Maity, J. Košmrlj and B. Sarkar, Dalton Trans., 2015, 44, 686-693.

23 L. Hettmanczyk, L. Suntrup, S. Klenk, C. Hoyer and B. Sarkar, Chem. - Eur. J., 2017, 23, 576-585.

24 A. Bolje, S. Hohloch, D. Urankar, A. Pevec, M. Gazvoda, B. Sarkar and J. Košmrlj, Organometallics, 2014, 33, 25882598.

25 A. Bolje, S. Hohloch, J. Košmrlj and B. Sarkar, Dalton Trans., 2016, 45, 15983-15993.

26 J. Beerhues, K. Fauché, F. Cisnetti, B. Sarkar and A. Gautier, Dalton Trans., 2019, 48, 8931-8936.

27 D. I. Bezuidenhout, G. Kleinhans, G. Guisado-Barrios, D. C. Liles, G. Ung and G. Bertrand, Chem. Commun., 2014, 50, 2431-2433.

28 G. Kleinhans, G. Guisado-Barrios, D. C. Liles, G. Bertrand and D. I. Bezuidenhout, Chem. Commun., 2016, 52, 35043507.

29 G. Kleinhans, M. M. Hansmann, G. Guisado-Barrios, D. C. Liles, G. Bertrand and D. I. Bezuidenhout, J. Am. Chem. Soc., 2016, 138, 15873-15876.

30 P. Pinter, C. M. Schüßlbauer, F. A. Watt, N. Dickmann, R. Herbst-Irmer, B. Morgenstern, A. Grünwald, T. Ullrich, 
M. Zimmer, S. Hohloch, D. M. Guldi and D. Munz, Chem. Sci., 2021, 12, 7401-7410.

31 I. Pryjomska-Ray, D. Zornik, M. Pätzel, K. B. Krause, L. Grubert, B. Braun-Cula, S. Hecht and C. Limberg, Chem. - Eur. J., 2018, 24, 5341-5349.

32 (a) L. Krause, R. Herbst-Irmer, G. M. Sheldrick and D. Stalke, J. Appl. Crystallogr., 2015, 48, 3-10; (b) G. M. Sheldrick, Acta Crystallogr., Sect. A: Found. Adv., 2015, 71, 3-8; (c) O. V. Dolomanov, L. J. Bourhis, R. J. Gildea, J. A. K. Howard and H. Puschmann, J. Appl. Crystallogr., 2009, 42, 339-341; (d) G. M. Sheldrick, Acta Crystallogr., Sect. C: Struct. Chem., 2015, 71, 3-8; (e) A. L. Spek, Acta Crystallogr., Sect. C: Struct. Chem., 2015, 71, 9-18; $(f)$ C. M. Hübschle, G. M. Sheldrick and B. Dittrich, J. Appl. Crystallogr., 2011, 44, 1281-1284.

33 Y. Wei, S.-X. Liu, H. Mueller-Bunz and M. Albrecht, ACS Catal., 2016, 6, 8192-8200.

34 Y. Wei, A. Petronilho, H. Mueller-Bunz and M. Albrecht, Organometallics, 2014, 33, 5834-5844.

35 G. W. Coates and D. R. Moore, Angew. Chem., Int. Ed., 2004, 43, 6618-6639.

36 A. J. Kamphuis, F. Picchioni and P. P. Pescarmona, Green Chem., 2019, 21, 406-448.

37 Y.-C. Su and B.-T. Ko, Inorg. Chem., 2021, 60, 852-865.

38 (a) S. Muthuramalingam, M. Velusamy and R. Mayilmurugan, Dalton Trans., 2021, 50, 7984-7994; (b) S. Muthuramalingam, M. Sankaralingam, M. Velusamy and R. Mayilmurugan, Inorg. Chem., 2019, 58, 1297512985.

39 (a) C.-S. Tan and T.-W. Kuo, J. Appl. Polym. Sci., 2005, 98, 750-757; (b) C.-S. Tan, C.-C. Juan and T.-W. Kuo, Polymer, 2004, 45, 1805-1814; (c) J. Hilf, M. Scharfenberg, J. Poon, C. Moers and H. Frey, Macromol. Rapid Commun., 2015, 36, 174-179; (d) H. Zhang and M. W. Grinstaff, J. Am. Chem. Soc., 2013, 135, 6806-6809; (e) M. Scharfenberg, J. Hilf and H. Frey, Adv. Funct. Mater., 2018, 28, 1704302.

40 W. J. Kruper and D. D. Dellar, J. Org. Chem., 1995, 60, 725727.

41 A. A. Bredikhin, Z. A. Bredikhina, D. V. Zakharychev and A. V. Pashagin, Tetrahedron: Asymmetry, 2007, 18, 12391244.

42 D.-W. Park, N.-Y. Mun, K.-H. Kim, I. Kim and S.-W. Park, Catal. Today, 2006, 115, 130-133, https://www.sciencedirect. com/science/article/pii/S0920586106001209.

43 C. J. Whiteoak, A. Nova, F. Maseras and A. W. Kleij, ChemSusChem, 2012, 5, 2032-2038.

44 C. J. Whiteoak, N. Kielland, V. Laserna, E. C. EscuderoAdán, E. Martin and A. W. Kleij, J. Am. Chem. Soc., 2013, 135, 1228-1231.

45 R. Inkum, A. Teerawutgulrag, P. Puangsombar and N. Rakariyatham, Maejo Int. J. Sci. Technol., 2012, 6, 372378. 